\title{
Systematic Review of Diagnostic Utility and Therapeutic Effectiveness of Cervical Facet Joint Interventions
}

Frank J.E. Falco, MD¹, Stephanie Erhart, MS¹, Bradley W. Wargo, DO², David A. Bryce, MD², Sairam Atluri, MD, Sukdeb Datta, MD, and Salim M. Hayek, MD, PhD ${ }^{6}$

From: ${ }^{1}$ Mid Atlantic Spine \& Pain Specialists, Newark, DE; ${ }^{2}$ Pain Management Center of Paducah, Paducah, $\mathrm{KY} ;{ }^{3} \mathrm{Advanced}$ Pain Management, Madison, Wl; ${ }^{4}$ Tri-State Spine Care Institute, Cincinnati, $\mathrm{OH}$; ${ }^{5}$ Vanderbilt University Medical Center, Nashville, TN; and ${ }^{6}$ University Hospitals of Cleveland and Outcomes Research Consortium, Cleveland, $\mathrm{OH}$.

Dr. Falco is Medical Director of the Mid Atlantic Spine \& Pain Specialists of Newark, DE, and Clinical Assistant Professor, Temple University Medical School, Philadelphia, PA. Stephanie Erhart, MLIS is Medical Librarian and Research Assistant of the Mid Atlantic Spine \& Pain Specialists of Newark, DE. Dr. Wargo is an Interventional Pain Physician at the Pain Management Center of Paducah,

Paducah, KY. Dr. Bryce is with Advanced

Pain Management, Madison, Wl, and Clinical Associated Profession of Anesthesiology, University of Wisconsin, Madison, WI. Dr. Atluri is a Staff Physician at Tri-State Spine Care Institute, Cincinnati, OH. Dr. Datta is

Director, Vanderbilt University Interventional Pain Program, Associate Professor, Dept. of Anesthesiology, Vanderbilt University Medical Center, Nashville, TN. Dr. Hayek is Chief of the Division of Pain Medicine, Department of Anesthesiology, University

Hospitals of Cleveland, Cleveland, $\mathrm{OH}$; and a member of the Outcomes Research Consortium, Cleveland, $\mathrm{OH}$.

Address correspondence: Frank Falco, MD Mid-Atlantic Spine

139 East Chestnut Hill Road Newark, DE 19713

E-mail: cssm01@aol.com

Disclaimer: Dr. Datta receives research support from Sucampo Pharmaceuticals and an honorarium from Smith and Nephew. Conflict of interest: None.

Manuscript received: $12 / 10 / 2008$ Revised manuscript received: $1 / 30 / 2009$ Accepted for publication: 02/12/2009

Free full manuscript: www.painphysicianjournal.com
Background: Chronic, recurrent neck pain is common and is associated with high pain intensity and disability, which is seen in $14 \%$ of the adult general population. Controlled studies have supported the existence of cervical facet or zygapophysial joint pain in $36 \%$ to $67 \%$ of these patients. However, these studies also have shown false-positive results in $27 \%$ to $63 \%$ of the patients with a single diagnostic block. There is also a paucity of literature investigating therapeutic interventions of cervical facet joint pain.

Study Design: A systematic review of cervical facet joint interventions.

Objective: To evaluate the accuracy of diagnostic facet joint nerve blocks and the effectiveness of cervical facet joint interventions.

Methods: Medical databases and journals were searched to locate all relevant literature from 1966 through December 2008 in the English language.

A review of the literature of the utility of facet joint interventions in diagnosing and managing facet joint pain was performed according to the Agency for Healthcare Research and Quality (AHRQ) criteria for diagnostic studies and observational studies and the Cochrane Musculoskeletal Review Group criteria as utilized for interventional techniques for randomized trials.

Level of Evidence: The level of evidence was defined as Level I, II, or III based on the quality of evidence developed by the U.S. Preventive Services Task Force (USPSTF).

Outcome Measures: For diagnostic interventions, studies must have been performed utilizing controlled local anesthetic blocks which achieve at minimum $80 \%$ relief of pain and the ability to perform previously painful movements. For therapeutic interventions, the primary outcome measure was pain relief (short-term relief up to 6 months and long-term relief greater than 6 months) with secondary outcome measures of improvement in functional status, psychological status, return to work, and reduction in opioid intake.

Results: Based on the utilization of controlled comparative local anesthetic blocks, the evidence for the diagnosis of cervical facet joint pain is Level I or II-1. The indicated evidence for therapeutic cervical medial branch blocks is Level II-1. The indicated evidence for radiofrequency neurotomy in the cervical spine is Level II-1 or II-2, whereas the evidence is lacking for intraarticular injections.

Limitations: A systematic review of cervical facet joint interventions is hindered by the paucity of published literature and lack of literature for intraarticular cervical facet joint injections.

Conclusions: The evidence for diagnosis of cervical facet joint pain with controlled comparative local anesthetic blocks is Level I or II-1. The indicated evidence for therapeutic facet joint interventions is Level II-1 for medial branch blocks, and Level II-1 or II-2 for radiofrequency neurotomy.

Key words: Chronic neck pain, cervical facet or zygapophysial joint pain, cervical medial branch blocks, controlled comparative local anesthetic blocks, cervical radiofrequency neurotomy, cervical intraarticular facet joint injections

Pain Physician 2009; 12:323-344 
hronic neck pain is common in the adult general population (1-9), with a lifetime prevalence of $26 \%$ to $71 \%(2,4)$. Significant economic, societal, and health impact cannot be ignored as it is similar to the impact of low back pain and is recognized as a source of disability in the working population (10-16).

Cervical intervertebral discs, cervical facet joints, atlanto-axial and atlanto-occipital joints, ligaments, fascia, muscles, and nerve root dura have been shown to be capable of transmitting pain in the cervical spine with resulting symptoms of neck pain, upper extremity pain, and headache. However, very little is known about the causes of neck pain since the epidemiologic studies do not describe either the source or cause of the pain. Yin and Bogduk (17) demonstrated the prevalence of discogenic pain in 16\%, zygapophysial joint pain in $55 \%$, and lateral atlanto-axial joint pain in $9 \%$, in 143 patients with chronic neck pain in a private practice pain clinic in the United States. In summary, diagnosis remained elusive in $32 \%$ of those patients who completed investigations. Based on controlled diagnostic blocks, cervical facet joints have been implicated as responsible for pain in the neck, head, and upper extremities in $36 \%$ to $67 \%$ of patients (18-27).

Cervical facet or zygapophysial joints have been shown to be a source of pain in the neck and referred pain in the head and upper extremities (28-32). Cervical facet joints are well innervated by the medial branches of the dorsal rami (33-37) with free and encapsulated nerve endings with nociceptors and mechanoreceptors $(34,35,38-43)$. Even though, a preponderance of evidence supports the existence of cervical facet joint pain and its prevalence utilizing controlled diagnostic blocks, a significant proportion of patients suspected of cervical facet joint pain present with false-positive results of $27 \%$ to $63 \%(20-25,44-48)$. Thus, to maintain the accuracy of diagnosis, facet joint blocks must be performed under controlled conditions, either with placebo or with controlled comparative local anesthetic blocks utilizing 2 local anesthetics of different durations of action. Further, the outcome measurement needs to be appropriate providing significant pain relief ( $\geq 80 \%$ ) and an outcome of the ability to perform previously painful movements with sustained pain relief.

A previous systematic review (46) showed strong evidence for diagnostic accuracy of cervical facet joint blocks. In addition, Rubinstein and van Tulder (49) in a best-evidence review of diagnostic procedures for neck and low back pain concluded that there was strong ev- idence for the diagnostic accuracy of facet joint blocks in the diagnosis of neck pain. Significant controversy surrounds various treatments utilized in the management of chronic neck pain arising from cervical facet joints $(1,4,48,50-57)$, even though diagnosis has been well established $(1,27,48,45-49)$. Thus far, the evidence for long-term therapeutic benefits of intraarticular injection of facet joints is limited $(1,50,58)$, for medial branch nerve blocks is promising $(1,48,50,59,60)$, and evidence for radiofrequency neurotomy is moderate to strong $(48,50,53,60-63)$. Cervical facet joint interventions for managing chronic neck pain are one of the most commonly performed interventions in the United States (64-70). With exploding medical costs and utilization, and repeated questions about the effectiveness of cervical facet joint interventions, it is essential to update the evidence periodically utilizing appropriate methodology (71).

Thus, this systematic review was undertaken to evaluate the accuracy of diagnostic facet joint blocks and the effectiveness of therapeutic cervical facet joint interventions.

\section{Methods}

\section{Literature Search}

A comprehensive literature search was conducted from 1966 through December 2008 in the English language. Databases included in the search were Medline, EMBASE, Cochrane Review Database, and Google Scholar. Other sources included Clinical Trial Registry, systematic reviews, narrative reviews, and cross-references to the reviews.

The search strategy emphasized chronic spinal pain of cervical facet joint origin with a focus on all types of diagnostic and therapeutic interventions. Search terminology included cervical facet joint, cervical facet joint pain, cervical diagnostic facet joint blocks, cervical facet joint intraarticular injections, cervical medial branch blocks, and cervical radiofrequency neurotomy.

\section{Diagnostic Facet Injections}

\section{Inclusion Criteria}

All studies published on the diagnosis of chronic cervical facet pain of at least 3 months duration were included in this review. In addition, only those studies utilizing diagnostic techniques were analyzed such as comparative controlled or placebo controlled blocks with 
fluoroscopic guidance. The principle standard for diagnosis of cervical facet joint pain was $\geq 80 \%$ pain relief for the duration of the local anesthetic effect and the ability to perform movements that were once painful.

The following studies were excluded from the review: essays, reviews, letters, editorials, abstracts, surveys, learning modules, and animal or cadaveric studies.

\section{Method of Review}

All articles retrieved from the search were screened for initial inclusion and exclusion criteria. Methodologic quality assessment was performed using the modified Agency for Healthcare Research and Quality (AHRQ) criteria (72). All manuscripts were reviewed by the first 2 authors. Any persistent disagreements were reviewed by a third author. If there was a conflict of interest with the reviewed manuscripts with authorship or any other type of conflict, the involved authors did not review the manuscripts for quality assessment, clinical relevance, evidence synthesis, or grading of evidence. Each study had to score at least 50 on a scale of $0-100$ for inclusion in the analysis. The weighted scoring was established from a consensus developed by the guidelines committee of the American Society of Interventional Pain Physicians (ASIPP) and has been modified with application in other evaluations $(48,73-79)$.

\section{Analysis of Evidence}

Diagnostic studies that were selected for this review were evaluated for the level of evidence using the modified U.S. Preventive Services Task Force (USPSTF) as illustrated in Table 1 (80). The rating scheme was modified to evaluate the diagnostic accuracy of diagnostic accuracy studies (81-83).

\section{Therapeutic Facet Joint Interventions}

\section{Inclusion Criteria}

Studies had to include evidence of the use of controlled diagnostic cervical facet joint injections or nerve blocks with $80 \%$ pain relief to be included in this systematic review. Three types of therapeutic interventions for facet joint pain were included in this study: intraarticular facet joint interventions, medial branch blocks, and medial branch neurotomy. All studies included were determined by outcome evaluations with at least a 6 month follow-up period and the use of appropriate statistical analysis.

\section{Outcome Parameters}

The primary outcome parameter was pain relief. The secondary outcome measures were functional improvement, change in psychological status, return to work, opioid use, and complications.

\section{Methodologic Quality Assessment}

The quality of each individual article used in this analysis was assessed by modified Cochrane review criteria with a weighted scoring system (84) for randomized trials and AHRQ quality criteria for assessment of observational studies (72). Only studies scoring at least 50 of 100 with the weighted scoring criteria were utilized for analysis. The weighted scoring for randomized trials was utilized by Koes et al (84) and Nelemans et al (85), and has been utilized in other evaluations $(48,73,74,79,86-94)$. The weighted scoring system for observational studies based on AHRQ criteria (72) was used with a developed score by the guidelines committee of ASIPP and has been utilized in multiple systematic evaluations $(73,74,86-94)$.

Table 1. Modified quality of evidence developed by USPSTF.

\begin{tabular}{|c|l||}
\hline I: & Evidence obtained from multiple properly conducted diagnostic accuracy studies. \\
\hline II-1: & Evidence obtained from at least one properly conducted diagnostic accuracy study of adequate size. \\
\hline II-2: & Evidence obtained from at least one properly designed small diagnostic accuracy study. \\
\hline II-3: & Evidence obtained from diagnostic studies of uncertainty. \\
\hline III: & Opinions of respected authorities, based on clinical experience descriptive studies and case reports or reports of expert committees. \\
\hline
\end{tabular}

Adapted from the U.S. Preventive Services Task Force (USPSTF) (80). 
Each study was evaluated by the first 2 authors for stated criteria and any disagreements were discussed by a third reviewer. If there was a conflict of interest with the reviewed manuscript with authorship or any other type of conflict, the involved authors did not review the manuscript for quality assessment, clinical relevance, evidence synthesis, or grading of evidence.

Only the studies scoring at least 50 of 100 with the weighted scoring criteria were utilized for analysis.

If there were 4 randomized trials evaluating any one of the techniques - namely intraarticular injections, medial branch blocks, or radiofrequency neurotomy, observational studies were not included in the methodologic quality assessment as well as the evidence synthesis.

\section{Clinical Relevance}

Clinical relevance of the included randomized trials was evaluated according to 5 questions recommended by the Cochrane Back Review Group $(95,96)$.

Each question was scored positive (+) if the clinical relevance item was met, negative $(-)$ if the item was not met, and unclear (?) if data were not available to answer the question.

In the Cochrane review of "Injection Therapy for
Subacute and Chronic Low Back Pain" (95) the authors considered a $20 \%$ improvement in pain scores (97) and a $10 \%$ improvement in functioning outcomes (98) to be clinically important. This review utilized stricter criteria than previous systematic reviews. Any relief of 6 months or less was considered as short-term, whereas Cochrane reviews (95) and others have considered 6 weeks as short-term and longer than 6 weeks as longterm. We also utilized methodologic quality assessment criteria for minimum inclusion, thus this systematic review is expected to provide robust results and the inclusion of observational studies is expected to improve the generalizability of this systematic review (99-103).

\section{Analysis of Evidence}

Analysis was conducted using 5 levels of evidence, ranging from Level I to III with 3 subcategories in Level II, as illustrated in Table 1 (80) developed by the USPSTF.

\section{Recommendations}

Grading recommendations were based on Guyatt et al's criteria with 6 Levels, $1 \mathrm{~A}-1 \mathrm{C}$ strong and 2A-2C weak as illustrated in Table 2 (104).

Table 2. Grading recommendations.

\begin{tabular}{|c|c|c|c|}
\hline $\begin{array}{c}\text { Grade of } \\
\text { Recommendation/ } \\
\text { Description }\end{array}$ & $\begin{array}{c}\text { Benefit vs Risk and } \\
\text { Burdens }\end{array}$ & $\begin{array}{l}\text { Methodological Quality of } \\
\text { Supporting Evidence }\end{array}$ & Implications \\
\hline $\begin{array}{l}\text { 1A/strong recommendation, } \\
\text { high-quality evidence }\end{array}$ & $\begin{array}{l}\text { Benefits clearly outweigh } \\
\text { risk and burdens, or vice } \\
\text { versa }\end{array}$ & $\begin{array}{l}\text { RCTs without important limitations } \\
\text { or overwhelming evidence from } \\
\text { observational studies }\end{array}$ & $\begin{array}{l}\text { Strong recommendation, can apply } \\
\text { to most patients in most circum- } \\
\text { stances without reservation }\end{array}$ \\
\hline $\begin{array}{l}\text { 1B/strong recommendation, } \\
\text { moderate quality evidence }\end{array}$ & $\begin{array}{l}\text { Benefits clearly outweigh } \\
\text { risk and burdens, or vice } \\
\text { versa }\end{array}$ & $\begin{array}{l}\text { RCTs with important limitations (inconsis- } \\
\text { tent results, methodological flaws, indirect, } \\
\text { or imprecise) or exceptionally strong } \\
\text { evidence from observational studies }\end{array}$ & $\begin{array}{l}\text { Strong recommendation, can apply } \\
\text { to most patients in most circum- } \\
\text { stances without reservation }\end{array}$ \\
\hline $\begin{array}{l}\text { 1C/strong recommendation, } \\
\text { low-quality or very low- } \\
\text { quality evidence }\end{array}$ & $\begin{array}{l}\text { Benefits clearly outweigh risk } \\
\text { and burdens, or vice versa }\end{array}$ & Observational studies or case series & $\begin{array}{l}\text { Strong recommendation but } \\
\text { may change when higher quality } \\
\text { evidence becomes available }\end{array}$ \\
\hline $\begin{array}{l}\text { 2A/weak recommendation, } \\
\text { high-quality evidence }\end{array}$ & $\begin{array}{l}\text { Benefits closely balanced } \\
\text { with risks and burden }\end{array}$ & $\begin{array}{l}\text { RCTs without important limitations } \\
\text { or overwhelming evidence from } \\
\text { observational studies }\end{array}$ & $\begin{array}{l}\text { Weak recommendation, best action } \\
\text { may differ depending on circum- } \\
\text { stances or patients' or societal values }\end{array}$ \\
\hline $\begin{array}{l}\text { 2B/weak recommendation, } \\
\text { moderate-quality evidence }\end{array}$ & $\begin{array}{l}\text { Benefits closely balanced } \\
\text { with risks and burden }\end{array}$ & $\begin{array}{l}\text { RCTs with important limitations } \\
\text { (inconsistent results, methodological flaws, } \\
\text { indirect, or imprecise) or exceptionally } \\
\text { strong evidence from observational studies }\end{array}$ & $\begin{array}{l}\text { Weak recommendation, best action } \\
\text { may differ depending on circum- } \\
\text { stances or patients' or societal values }\end{array}$ \\
\hline $\begin{array}{l}\text { 2C/weak recommendation, } \\
\text { low-quality or very low- } \\
\text { quality evidence }\end{array}$ & $\begin{array}{l}\text { Uncertainty in the estimates } \\
\text { of benefits, risks, and burden; } \\
\text { benefits, risk, and burden may } \\
\text { be closely balanced }\end{array}$ & Observational studies or case series & $\begin{array}{l}\text { Very weak recommendations; } \\
\text { other alternatives may be equally } \\
\text { reasonable }\end{array}$ \\
\hline
\end{tabular}

Adapted from Guyatt G et al. Grading strength of recommendations and quality of evidence in clinical guidelines. Report from an American College of Chest Physicians task force. Chest 2006; 129:174-181 (104). 


\section{Outcome of the Studies}

A study was judged to be positive if the therapeutic facet joint interventions were clinically relevant and effective, either with a placebo control or active control in randomized trials. This indicates that the difference in the effect for the primary outcome measure was statistically significant at the conventional $5 \%$ level. In a negative study, no difference between the study treatments or no improvement from baseline was found. Further, the outcomes were judged at the reference point with positive or negative results reported at 3 months, 6 months, and one year. For observational studies, a study was judged to be positive if the authors concluded that the therapeutic facet joint interventions were effective, with outcomes reported at the reference point with positive or negative results at 3 months, 6 months, and one year. Relief of 6 months or less was considered as short-term and relief of longer than 6 months was considered as long-term.

\section{Results}

\section{Diagnostic Facet Joint Injections}

A literature search was carried out for diagnostic cervical facet joint interventions as shown in Fig. 1.

The search yielded 76 articles relevant to cervical facet joint pain and its diagnosis by cervical facet injection procedures (Fig. 1). However, only 14 of these studies pertaining to cervical facet joint pain diagnostic injections met inclusion criteria $(17-27,36,44,105)$.

\section{Methodological Quality Assessment}

A total of 9 studies met the inclusion criteria for methodological assessment based on the inclusion criteria. Manchikanti et al in one study (25) utilized $75 \%$ relief as the criteria for a positive diagnostic block, thus this study was excluded from methodologic quality assessment. Two studies by Manchikanti et al $(22,27)$ were subgroup analyses of a study by Manchukonda et al (20). The study by Bogduk and Aprill (105) was excluded due to uncontrolled blocks utilizing only a single block. The study by Barnsley and Bogduk (36) was excluded as this study evaluated specificity of medial branch blocks rather than accuracy.

All 9 studies meeting inclusion criteria (17$21,23,24,26,44)$ scored above 50 with scores of 55 to 70. The analysis and specifics of these 9 studies are summarized in Tables 3 and 4.

The first study of accuracy of controlled diagnostic blocks in cervical spine was published in 1993 (44).
They determined the false-positive rate of anesthetic blocks of the medial branches of the cervical dorsal rami by comparison between single diagnostic blocks and a criterion standard of double blind, controlled, differential anesthetic blocks. They showed a falsepositive rate of single blocks of $27 \%(95 \% \mathrm{Cl}, 15 \%$, $38 \%$ ). Consequently, they recommended that uncontrolled diagnostic blocks are compromised by a significant false-positive rate that seriously detracts from the specificity of the test.

In 1995, Barnsley et al (18) determined the prevalence of chronic cervical zygapophysial joint pain after whiplash. They studied 50 consecutive referred patients with chronic neck pain after whiplash injury using double blind, controlled, diagnostic blocks of the cervical zygapophysial joints by blocking the joint on 2 separate occasions, either with lignocaine or bupivacaine in random order. They utilized the criterion standard of a positive joint if only either definite or complete relief of pain was achieved and both blocks relieved the patient's pain and bupivacaine provided longer relief. They identified a prevalence of facet joint pain in chronic whiplash patients of $54 \%(95 \% \mathrm{Cl}, 40 \%, 68 \%)$.

Lord et al (19) determined the prevalence of cervical zygapophysial joint pain among patients with chronic neck pain after whiplash injury. They evaluated 68 patients referred for chronic neck pain after whiplash. Two different local anesthetics and a placebo injection of normal saline were administered in random order and under double blind folded conditions. A positive diagnosis was made if the patient's pain was completely and reproducibly relieved by each local anesthetic but not by the placebo injection. The prevalence of facet joint pain with placebo-control blocks was revealed to be $60 \%$ below the $\mathrm{C} 2-\mathrm{C} 3$ zygapophysial joint ( $95 \% \mathrm{Cl}, 46 \%, 73 \%)$.

Manchikanti and coauthors in multiple publications $(20,21,23,24)$ evaluated prevalence and false-positive rates of diagnostic blocks. In all included studies they utilized a criterion standard of $80 \%$ pain relief with the ability to perform previously painful movements without pain utilizing $1 \%$ lidocaine. In a large study of 500 patients in which prevalence of facet joint pain in chronic spinal pain of cervical, thoracic, and lumbar regions were evaluated (21), 255 patients were evaluated for neck pain with a prevalence of $55 \%(95 \% \mathrm{Cl}, 49 \%$, $61 \%$ ) with a false-positive rate with single blocks with lidocaine of $63 \%(95 \% \mathrm{Cl}, 54 \%, 72 \%)$. The second large study by Manchukonda et al (20) evaluated 500 patients with 438 patients meeting the inclusion criteria 


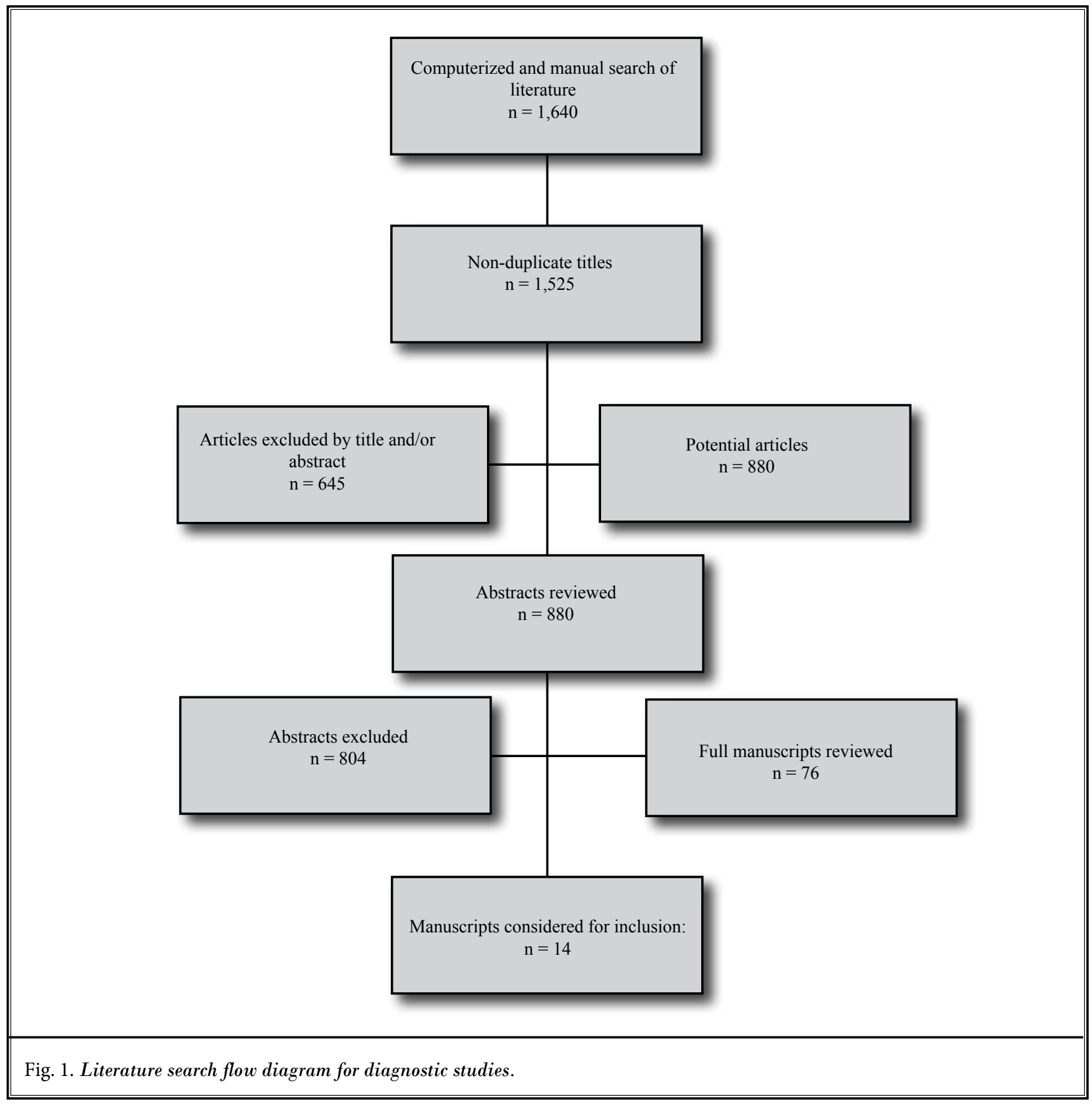

and 251 patients with cervical pain. Utilizing the same criterion standard, prevalence of cervical facet joint pain was determined to be $39 \%(95 \% \mathrm{Cl}, 32 \%, 45 \%)$, with a false-positive rate of single blocks in the cervical region of $45 \%(95 \% \mathrm{Cl}, 37 \%, 52 \%)$.

The first study outside Bogduk's group $(18,19,44)$ was by Manchikanti et al (25) and was not included in the evidence synthesis. They showed a prevalence rate of facet joint pain in chronic neck pain of $60 \%(95 \% \mathrm{Cl}$,
$50 \%, 70 \%)$ with a false-positive rate of single diagnostic block with lidocaine of $40 \%(95 \% \mathrm{Cl}, 34 \%, 46 \%)$.

In another study, Manchikanti et al (23) compared the correlation of facet joint pain in lumbar and cervical regions. They concluded that the prevalence of cervical facet joint pain was $67 \%$ with a false-positive rate of $63 \%$ using a single block, in patients presenting with low back and neck pain, and noted a significant correlation of $94 \%$ between patients with confirmed lum- 
Cervical Facet Joint Interventions

Table 3. Methodological quality assessment and scoring of cervical diagnostic facet joint nerve block studies.

\begin{tabular}{|c|c|c|c|c|c|c|c|c|}
\hline \multirow[b]{2}{*}{ STUDY } & \multirow[b]{2}{*}{$\begin{array}{c}\text { Study } \\
\text { Population } \\
\text { (15) }\end{array}$} & \multirow[b]{2}{*}{$\begin{array}{c}\text { Adequate } \\
\text { Description } \\
\text { of Test (10) }\end{array}$} & \multicolumn{2}{|c|}{$\begin{array}{c}\text { Appropriate Reference } \\
\text { Standard (30) } \\
\end{array}$} & \multicolumn{2}{|c|}{$\begin{array}{c}\text { Blinded Comparison of Test } \\
(\mathbf{3 0})\end{array}$} & \multirow[b]{2}{*}{$\begin{array}{l}\begin{array}{c}\text { Avoidance } \\
\text { of } \\
\text { Verification } \\
\text { Bias (15) }\end{array} \\
\text { (15) }\end{array}$} & \multirow[b]{2}{*}{$\begin{array}{l}\text { TOTAL } \\
(\mathbf{1 0 0})\end{array}$} \\
\hline & & & $\begin{array}{c}\text { Appropriate } \\
\text { reference } \\
\text { standard } \\
\text { (gold } \\
\text { standard) } \\
\text { used for } \\
\text { comparison } \\
\text { (15) }\end{array}$ & $\begin{array}{c}\text { Reference } \\
\text { standard } \\
\text { reproducible } \\
\text { (15) }\end{array}$ & $\begin{array}{c}\text { Evaluation } \\
\text { of test } \\
\text { without } \\
\text { knowledge } \\
\text { of disease } \\
\text { status, if } \\
\text { possible (15) }\end{array}$ & $\begin{array}{l}\text { Independent, } \\
\text { blind } \\
\text { interpretation } \\
\text { of test and } \\
\text { reference (15) }\end{array}$ & & \\
\hline \begin{tabular}{|l} 
Barnsley et al \\
1995 (18)
\end{tabular} & 15 & 10 & 10 & 15 & - & 10 & 15 & 75 \\
\hline $\begin{array}{l}\text { Barnsley et al } \\
1993 \text { (44) }\end{array}$ & 15 & 10 & 10 & 15 & - & 10 & 15 & 75 \\
\hline $\begin{array}{l}\text { Lord et al } \\
1996(19) \\
\end{array}$ & 15 & 10 & 10 & 15 & - & 10 & 15 & 75 \\
\hline $\begin{array}{l}\text { Manchikanti } \\
\text { et al } 2002 \text { (23) }\end{array}$ & 15 & 10 & 10 & 15 & - & 10 & 15 & 75 \\
\hline $\begin{array}{l}\text { Manchikanti } \\
\text { et al } 2004(21)\end{array}$ & 15 & 10 & 10 & 15 & - & 10 & 15 & 75 \\
\hline $\begin{array}{l}\text { Manchu- } \\
\text { konda et al } \\
2007(20)\end{array}$ & 15 & 10 & 10 & 15 & - & 10 & 5 & 65 \\
\hline $\begin{array}{l}\text { Manchikanti } \\
\text { et al } 2008 \\
(24)\end{array}$ & 15 & 10 & 10 & 15 & - & 10 & 5 & 65 \\
\hline $\begin{array}{l}\text { Speldewinde } \\
\text { et al } 2001 \text { (26) }\end{array}$ & 15 & 10 & 10 & 15 & - & 10 & - & 50 \\
\hline $\begin{array}{l}\text { Yin and Bog- } \\
\text { duk } 2008 \text { (17) }\end{array}$ & 15 & 10 & 10 & 15 & - & 10 & - & 60 \\
\hline
\end{tabular}

( ) weighted item score

Methodological criteria and scoring adapted from West S et al. Systems to Rate the Strength of Scientific Evidence, Evidence Report, Technology Assessment No. 47. AHRQ Publication No. E016 (72).

Table 4. Data of prevalence and false-positive rates of cervical diagnostic facet joint blocks.

\begin{tabular}{|c|c|c|c|c|}
\hline Study & $\begin{array}{c}\text { Methodologic } \\
\text { Criteria }\end{array}$ & \# of Subjects & Prevalence Estimates & False-Positive Rate \\
\hline Barnsley et al 1995 (18) & 75 & 50 & $54 \%(95 \%$ CI, $40 \%, 68 \%)$ & NA \\
\hline Barnsley et al 1993 (44) & 75 & 55 & NA & $27 \%(95 \%$ CI $, 15 \%, 38 \%)$ \\
\hline Lord et al 1996 (19) & 75 & 68 & $60 \%(95 \%$ CI, $46 \%, 73 \%)$ & NA \\
\hline Manchikanti et al 2002 (23) & 75 & 120 & $67 \%(95 \%$ CI, $58 \%, 75 \%)$ & $63 \%(95 \%$ CI $48 \%, 78 \%)$ \\
\hline Manchikanti et al 2004 (21) & 75 & 255 of 500 & $55 \%$ (95\% CI, 49\%, 61\%) & $63 \%(95 \%$ CI $54 \%, 72 \%)$ \\
\hline Manchukonda et al 2007 (20) & 65 & 251 of 500 & $39 \%(95 \%$ CI, $32 \%, 45 \%)$ & $45 \%(95 \%$ CI $37 \%, 52 \%)$ \\
\hline Manchikanti et al 2008 (24) & 65 & $\begin{array}{l}\text { Non-Surgery: } \\
206 \\
\text { Post-Surgery: } \\
45\end{array}$ & $\begin{array}{c}\text { Non-Surgery } \\
39 \%(95 \% \text { CI, 33\%, 46\%) } \\
\text { Post-Surgery } \\
36 \%(95 \% \text { CI, 22\%, 51\%) }\end{array}$ & $\begin{array}{c}\text { Non-Surgery } \\
43 \%(95 \% \text { CI } 35 \%, 52 \%) \\
\text { Post-Surgery } \\
50 \%(95 \% \text { CI } 32 \%, 68 \%)\end{array}$ \\
\hline Speldewinde et al 2001 (26) & 50 & 97 & $36 \%(95 \%$ CI, $27 \%, 45 \%)$ & NA \\
\hline Yin and Bogduk 2008 (17) & 60 & 143 & $55 \% *(95 \%$ CI, $38 \%, 62 \%)$ & NA \\
\hline
\end{tabular}

$\mathrm{NA}=$ not available or not applicable; $\mathrm{CI}=$ confidence interval; ${ }^{*}=$ adjusted 
bar facet joint pain who also presented with cervical facet joint pain. Manchikanti et al (24) also evaluated the prevalence of facet joint related chronic neck pain in post-surgical and non-surgical patients and found no significant difference between the groups with prevalence or the false-positive rates of single blocks with $36 \%$ and $50 \%$ in the post-surgical group compared with $39 \%$ and $43 \%$ in the non-surgical patients.

Speldewinde et al (26) determined the prevalence of cervical zygapophysial joint pain in a speciality clinical setting of $36 \%(95 \% \mathrm{Cl}, 27 \%, 45 \%)$. Finally, Yin and Bogduk (17) also evaluated cervical facet joint pain and provided prevalence; however, they cautioned that the study was not designed to establish prevalence of the various causes of neck pain in the general community or even a particular sample of that community. Still, they provided useful information about an anatomical diagnosis with minimally invasive diagnostic tests in accordance with validated standards.

\section{Diagnostic Accuracy}

Accuracy wasestablished in 5 studies $(20,21,23,24,44)$ based on a false-positive rate of $27 \%$ to $63 \%$ with single diagnostic blocks with $95 \%$ confidence intervals $(\mathrm{Cl})$ ranging from $15 \%$ to $78 \%$. The recent large study (20) with $80 \%$ pain relief criterion standard showed a falsepositive rate of $45 \%$ with a single block with a $95 \% \mathrm{Cl}$ of $37 \%$ to $52 \%$.

\section{Prevalence}

The prevalence was found to be $36 \%$ to $67 \%$ using controlled diagnostic blocks with $95 \% \mathrm{Cls}$ of $22 \%$ to $75 \%$, based on 8 studies $(17-21,23,24,26)$.

The recent large study by Manchikanti et al (20) showed a prevalence rate of $39 \%$ with $95 \% \mathrm{Cl}$ of $32 \%$ to $45 \%$.

\section{Confounding Factors}

Potential and real confounding factors were assessed in the several studies included in this systemic review. Influence of age, surgery, and psychopathology were evaluated in 3 reports and found not to have significant impact on the prevalence of cervical facet joint related chronic neck pain $(22,24,27)$. In an evaluation of 438 patients by Manchikanti et al (27), the prevalence of cervical facet joint pain in patients with psychopathology ranged from $38 \%$ to $43 \%$, whereas in patients without psychopathology, the prevalence was $28 \%$. False-positive rates were also $58 \%$ in patients with psychopathology, ranging from $39 \%$ to $42 \%$ in patients without psychopathology. Prevalence was $43 \%$ versus $30 \%$ in patients with or without major depression $(P$ $=0.05), 42 \%$ versus $30 \%$ in patients with or without generalized anxiety disorder, and $38 \%$ versus $39 \%$ in patients with or without somatization disorder.

Evaluation of the prevalence of facet joint pain in patients with or without prior surgical history (24) showed no significant differences with prevalence of $36 \%$ and $39 \%$ and false-positive rates of $50 \%$ or $43 \%$ in post-surgical and non-surgical patients.

Age-related prevalence of cervical facet joint pain showed no significant differences (22).

\section{Criterion Standard}

\section{Validity}

Controlled cervical facet joint medial branch blocks have been an established method to diagnose cervical facet joint pain either with placebo-control or controlled comparative local anesthetic blocks that meet specific criteria of pain relief and functional improvement $(18,19,44,54)$. Pain relief $(106,107)$ and long-term follow up are employed as the criterion standards and are accepted across different medical disciplines $(100,106-108)$. Long-term relief of facet joint interventions has been demonstrated $(1,48,49,59-63,108-110)$.

\section{Study Designs}

All the studies included in the methodologic quality assessment met inclusion criteria as well as study design criteria. There has been significant controversy over the study designs with some reviewers calling for randomized controlled trials (RCTs) for diagnostic interventions $(50,51)$. However, the design accuracy of diagnostic studies involves consecutive or non-consecutive allocation and observational studies $(48,81-83,111)$.

\section{Level of Evidence}

The level of evidence is Level I or II-1 based on the 9 reviewed studies.

\section{Therapeutic Facet Joint Interventions}

A comprehensive literature search was performed for cervical intraarticular facet joint injections, cervical medial branch blocks, and cervical radiofrequency neurotomy (Fig. 2). The entire search yielded a total of 17 studies relevant to therapeutic cervical facet interventions. 


\section{Randomized Trials}

\section{Methodologic Quality Assessment}

Of the 6 randomized trials identified evaluating the effectiveness of cervical therapeutic facet joint interventions $(58,60,61,109,112,113), 2$ studies met inclusion criteria for methodologic quality assessment $(60,61)$. Therapeutic medial branch nerve blocks by Manchikanti et al (109) was a preliminary report of a one year follow-up study (60). Barnsley et al's study (58) was not included as it included short-term follow-up of only 12 weeks. The study by Wallis et al
(113) evaluated the resolution of psychological distress of whiplash patients following treatment by radiofrequency neurotomy, with short-term (3-month) follow-up. Haspeslagh et al's (112) study evaluating radiofrequency for cervicogenic headache with 15 patients receiving a sequence of radiofrequency treatments with cervical facet joint denervation, followed by cervical dorsal root ganglion lesions when necessary, and the other 15 patients undergoing local injections with steroid and anesthetic at the greater occipital nerve followed by transcutaneous electrical nerve stimulation when necessary. This study was ex-

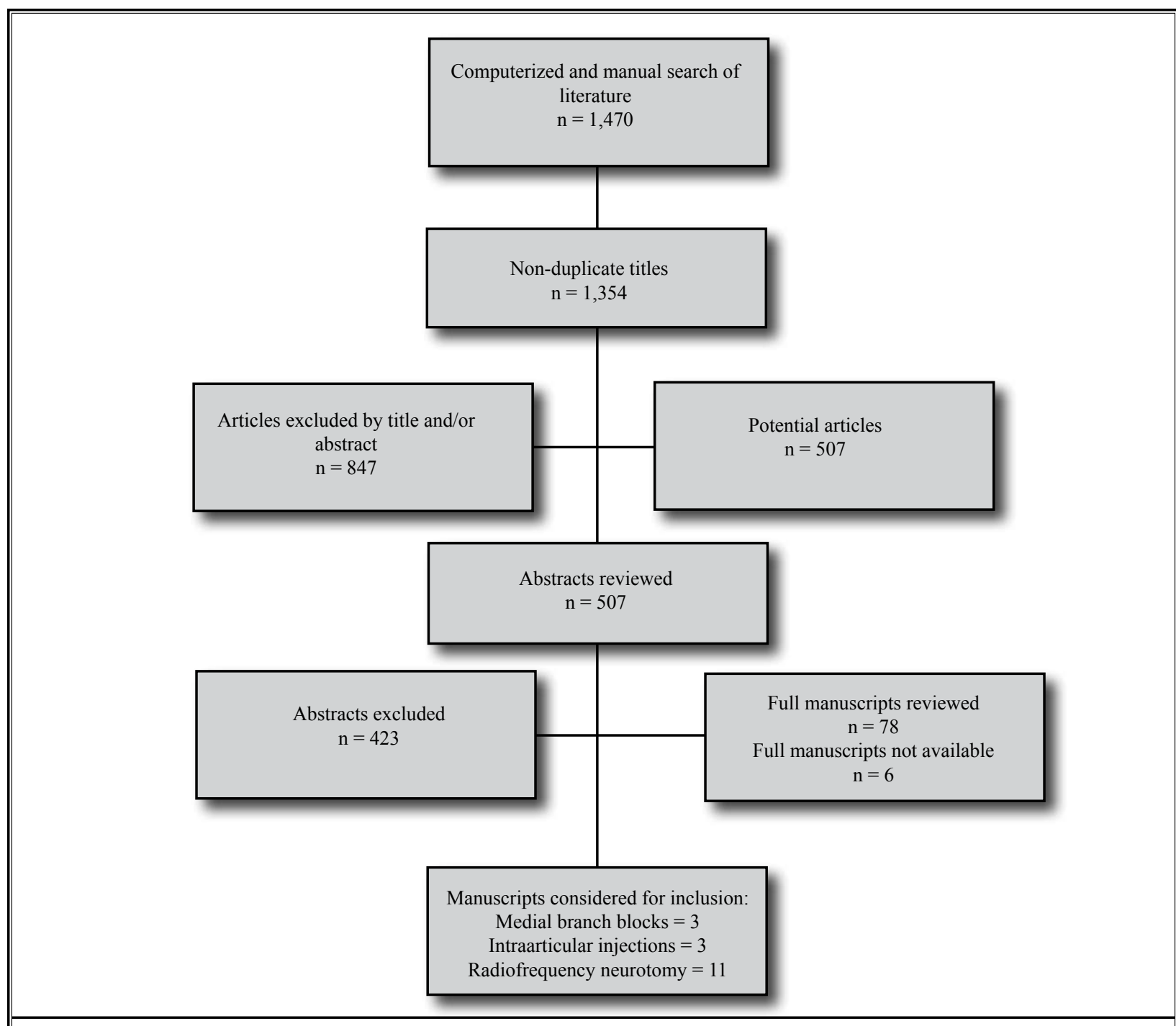

Fig. 2. The flow diagram illustrating literature evaluating cervical facet joint interventions. 
cluded. There were diagnostic flaws as well as technical flaws in performing the procedures. The treatments were targeting 2 different structures, namely cervical facet joints and cervical root ganglion compared to occipital nerves. Thus, 4 trials were excluded $(58,109,112,113)$.

Table 5 illustrates the methodologic assessment of randomized clinical trials evaluating the role of cervical facet joint interventions. The quality assessment criteria was 67 for Lord et al (61) and 76 for Manchikanti et al (60).

\section{Clinical Relevance Assessment}

Table 6 illustrates clinical relevance assessment of both randomized trials.

\section{Observational Studies}

Of the 11 observational studies $(59,62,63,110,114-$ 120), 2 studies evaluated the role of intraarticular facet joint injections $(115,116)$, one study evaluated the role of therapeutic medial branch blocks (59), and 6 studies provided the results of cervical medial branch neurotomy $(62,63,110,114,117-120)$.

Table 7 illustrates the methodologic quality assessment criteria of observational studies. Both intraarticular injection studies $(115,116)$ failed to meet the criteria. Folman et al (115) was excluded because the diagnosis was reached using a single diagnostic block and the follow-up was for less than 6 months. Kim et al (116) was excluded based on the use of an imaging diagnosis instead of use of the controlled diagnostic blocks.

Table 5. Methodological assessment of randomized clinical trials of therapeutic role of cervical facet joint interventions.

\begin{tabular}{|c|c|c|c|c|}
\hline \multicolumn{2}{|r|}{ CRITERION } & $\begin{array}{l}\text { WEIGHTED } \\
\text { SCORE (points) }\end{array}$ & $\begin{array}{l}\text { Lord et al } \\
\quad(61)\end{array}$ & $\begin{array}{l}\text { Manchikanti } \\
\text { et al (60) }\end{array}$ \\
\hline \multicolumn{5}{|c|}{ Study population } \\
\hline A & Homogeneity & 2 & 2 & 2 \\
\hline B & Comparability of relevant baseline characteristics & 5 & 3 & 5 \\
\hline $\mathrm{C}$ & Randomization procedure adequate & 4 & 4 & 4 \\
\hline $\mathrm{D}$ & Drop-outs described for each study group separately & 3 & 3 & 3 \\
\hline \multirow[t]{2}{*}{$\mathrm{E}$} & $\leq 20 \%$ loss for follow-up & 2 & 2 & 2 \\
\hline & $\leq 10 \%$ loss for follow-up & 2 & 0 & 2 \\
\hline \multirow[t]{2}{*}{$\mathrm{F}$} & $>50$ subject in the smallest group & 8 & 0 & 8 \\
\hline & $>100$ subjects in the smallest group & 9 & 0 & 0 \\
\hline \multicolumn{5}{|c|}{ Interventions } \\
\hline G & Interventions included in protocol and described & 10 & 10 & 10 \\
\hline $\mathrm{H}$ & Pragmatic study & 5 & 5 & 5 \\
\hline I & Co-interventions avoided or similar & 5 & 5 & 5 \\
\hline $\mathrm{J}$ & Placebo-controlled & 5 & 0 & 0 \\
\hline \multicolumn{5}{|c|}{ Effect } \\
\hline $\mathrm{K}$ & Patients blinded & 5 & 5 & 5 \\
\hline $\mathrm{L}$ & Outcome measures relevant & 10 & 10 & 10 \\
\hline M & Blinded outcome assessments & 10 & 5 & 0 \\
\hline $\mathrm{N}$ & Follow-up period adequate & 5 & 3 & 5 \\
\hline \multicolumn{5}{|c|}{ Data-presentation and analysis } \\
\hline $\mathrm{O}$ & Intention-to-treat analysis & 5 & 5 & 5 \\
\hline $\mathrm{P}$ & $\begin{array}{l}\text { Frequencies of most important outcomes presented for each treatment } \\
\text { group }\end{array}$ & 5 & 5 & 5 \\
\hline \multicolumn{2}{|c|}{$\begin{array}{lr} & \text { TOTAL SCORE } \\
\end{array}$} & 100 & 67 & 76 \\
\hline
\end{tabular}

Methodological criteria and scoring adapted from Koes BW et al. Efficacy of epidural steroid injections for low-back pain and sciatica: A systematic review of randomized clinical trials. Pain 1995; 63:279-288 (84). 
Table 6. Clinical relevance of randomized clinical trials evaluating the effectiveness of cervical facet joint interventions.

\begin{tabular}{|l|c|c|}
\hline \hline & $\begin{array}{c}\text { Lord et al } \\
\text { (61) }\end{array}$ & $\begin{array}{c}\text { Manchikanti et al } \\
\text { (60) }\end{array}$ \\
\hline $\begin{array}{l}\text { A) Are the patients described in detail so that you can decide whether they are comparable } \\
\text { to those that you see in your practice? }\end{array}$ & + & + \\
\hline $\begin{array}{l}\text { B) Are the interventions and treatment settings described well enough so that you can } \\
\text { provide the same for your patients? }\end{array}$ & + & + \\
\hline C) Were all clinically relevant outcomes measured and reported? & - & + \\
\hline D) Is the size of the effect clinically important? & + & + \\
\hline E) Are the likely treatment benefits worth the potential harms? & $4 / 5$ & + \\
\hline TOTAL CRITERIA MET & $5 / 5$ \\
\hline
\end{tabular}

+ = positive; - = negative; ? = unclear

Scoring adapted from Staal JB et al. Injection therapy for subacute and chronic low-back pain. Cochrane Database Syst Rev 2008; 3:CD001824 (96).

Among the studies evaluating the effectiveness of medial branch blocks, only one study was available which met the inclusion criteria (59).

Among the 9 studies evaluating radiofrequency neurotomy $(62,63,110,114,117-121), 4$ of the studies met the inclusion criteria $(62,63,110,121)$.

Cohen et al (120) analyzed their data retrospectively and attempted to identify factors influencing the outcomes of cervical facet neurotomy with patients derived from $50 \%$ or $80 \%$ relief with a single block. Schaerer (117) and Tzaan and Tasker and (118) included patients with a single diagnostic block and appropriate information was not available. Further, Tzaan and Tasker also performed these procedures under general anesthesia. Thus, they were excluded.

Shin et al (114) was excluded as they included patients with controlled comparative local anesthetic blocks, but $50 \%$ relief following the diagnostic blocks rather than $80 \%$. Lord et al (119) performed an audit of the experience of the authors with 19 patients to determine whether there was sufficient merit in the amended procedure to justify a randomized, doubleblind, controlled trial, with 10 patients undergoing third occipital neurotomy with only 4 patients obtaining long lasting relief. Thus, this study was excluded from the methodologic quality assessment.

\section{Intraarticular Facet Joint Blocks}

There were no studies meeting the criteria for inclusion, either RCTs or observational studies.

\section{Medial Branch Blocks}

Our search strategy included 3 studies of medial branch blocks with 2 of them meeting methodologic assessment criteria $(59,60)$. Of these, one study was a randomized trial (60) and the second study was an observational study (59). The methodologic quality assessment score of the randomized trial was $76(60)$, whereas for the observational evaluation (59) it was 69 .

\section{Study Characteristics}

Manchikanti et al (60) in a double blind, randomized, controlled trial evaluated the role of therapeutic cervical medial branch blocks in managing chronic cervical facet joint pain utilizing an active control equivalence or non-inferiority design $(122,123)$. The study was conducted based on the Consolidated Standards of Reporting Trials (CONSORT) criteria $(122,123)$, with inclusion of 120 patients meeting the diagnostic criteria of cervical facet joint pain by means of comparative, controlled diagnostic blocks with $80 \%$ pain relief. Group I consisted of medial branch blocks with bupivacaine, whereas Group II consisted of cervical medial branch blocks with bupivacaine and steroids. The outcome assessments included numeric pain scores, Neck Pain Disability Index (NDI), opioid intake, and work status at baseline, 3 months, 6 months, and 12 months. Significant pain relief ( $\geq 50 \%)$ and functional status improvement $(\geq 40 \%$ ) of NDI were observed at 3 months, 6 months, and 12 months in over $83 \%$ of the patients. The average number of treatments for one year was $3.5 \pm 1.0$ in the non-steroid group and 3.4 \pm 0.9 in the steroid group. Duration of average pain relief with each procedure was $14 \pm 6.9$ weeks in the non-steroid group and it was $16 \pm 7.9$ weeks in the steroid group. Significant relief and functional improvement was reported for 46 to 48 weeks in a one year period. The authors concluded that therapeutic cervi- 
Table 7. Methodologic quality assessment criteria for observational studies of cervical facet joint interventions.

\begin{tabular}{|c|c|c|c|c|c|c|}
\hline CRITERION & $\begin{array}{c}\text { Weighted } \\
\text { Score } \\
\text { (points) } \\
\end{array}$ & $\begin{array}{c}\text { Manchikanti } \\
\text { et al } \\
(59) \\
\end{array}$ & $\begin{array}{c}\text { Sapir and } \\
\text { Gorup } \\
(62) \\
\end{array}$ & $\begin{array}{c}\text { Barnsley } \\
(\mathbf{1 1 0})\end{array}$ & $\begin{array}{l}\text { McDonald } \\
\text { et al (63) }\end{array}$ & $\begin{array}{c}\text { Govind et } \\
\text { al (121) }\end{array}$ \\
\hline 1. Study Question & 2 & 2 & 2 & 2 & 2 & 2 \\
\hline - Clearly focused and appropriate question & 2 & 2 & 2 & 2 & 2 & 2 \\
\hline 2. Study Population & 8 & 5 & 5 & 5 & 5 & 5 \\
\hline - Description of study population & 5 & 5 & 5 & 5 & 5 & 5 \\
\hline - Sample size justification & 3 & -- & -- & -- & -- & -- \\
\hline 3. Comparability of Subjects & 22 & 14 & 22 & 14 & 17 & 5 \\
\hline - Specific inclusion/exclusion criteria for all groups & 5 & 5 & 5 & 5 & 5 & 5 \\
\hline - Criteria applied equally to all groups & 3 & -- & 3 & -- & 3 & -- \\
\hline $\begin{array}{l}\text { - Comparability of groups at baseline with regard } \\
\text { to disease status and prognostic factors }\end{array}$ & 3 & 3 & 3 & 3 & 3 & -- \\
\hline $\begin{array}{l}\text { - Study groups comparable to non-participants } \\
\text { with regard to confounding factors }\end{array}$ & 3 & 3 & 3 & 3 & 3 & -- \\
\hline - Use of concurrent controls & 5 & 0 & 5 & -- & -- & -- \\
\hline $\begin{array}{l}\text { - Comparability of follow-up among groups at each } \\
\text { assessment }\end{array}$ & 3 & 3 & 3 & 3 & 3 & -- \\
\hline 4. Exposure or Intervention & 11 & 8 & 11 & 8 & 11 & 8 \\
\hline - Clear definition of exposure & 5 & 5 & 5 & 5 & 5 & 5 \\
\hline - Measurement method standard, valid and reliable & 3 & 3 & 3 & 3 & 3 & 3 \\
\hline - Exposure measured equally in all study groups & 3 & -- & 3 & -- & 3 & -- \\
\hline 5. Outcome measures & 20 & 15 & 15 & 10 & 15 & 15 \\
\hline - Primary/secondary outcomes clearly defined & 5 & 5 & 5 & 5 & 5 & 5 \\
\hline - Outcomes assessed blind to exposure or intervention & 5 & 0 & -- & -- & -- & -- \\
\hline $\begin{array}{l}\text { - Method of outcome assessment standard, valid } \\
\text { and reliable }\end{array}$ & 5 & 5 & 5 & -- & 5 & 5 \\
\hline - Length of follow-up adequate for question & 5 & 5 & 5 & 5 & 5 & 5 \\
\hline 6. Statistical Analysis & 19 & 10 & 14 & -- & -- & -- \\
\hline - Statistical tests appropriate & 5 & 5 & 5 & -- & -- & -- \\
\hline - Multiple comparisons taken into consideration & 3 & 3 & 3 & -- & -- & -- \\
\hline $\begin{array}{l}\text { - Modeling and multivariate techniques } \\
\text { appropriate }\end{array}$ & 2 & 2 & 2 & -- & -- & -- \\
\hline - Power calculation provided & 2 & -- & 2 & -- & -- & -- \\
\hline - Assessment of confounding & 5 & -- & 2 & -- & -- & -- \\
\hline - Dose-response assessment if appropriate & 2 & -- & -- & -- & -- & -- \\
\hline 7. Results & 8 & 5 & 8 & 5 & 5 & 5 \\
\hline $\begin{array}{l}\text { - Measure of effect for outcomes and appropriate } \\
\text { measure of precision }\end{array}$ & 5 & 5 & 5 & 5 & 5 & 5 \\
\hline - Adequacy of follow-up for each study group & 3 & -- & 3 & -- & -- & -- \\
\hline 8. Discussion & 5 & 5 & 5 & 5 & 5 & 5 \\
\hline $\begin{array}{l}\text { - Conclusions supported by results with possible } \\
\text { biases and limitations taken into consideration }\end{array}$ & 5 & 5 & 5 & 5 & 5 & 5 \\
\hline 9. Funding or Sponsorship & 5 & 5 & 5 & 5 & 5 & 5 \\
\hline - Type and sources of support for study & 5 & 5 & 5 & 5 & 5 & 5 \\
\hline TOTAL SCORE = & 100 & 69 & 87 & 54 & 65 & 50 \\
\hline
\end{tabular}

Adapted and modified from West S et al. Systems to Rate the Strength of Scientific Evidence, Evidence Report, Technology Assessment No. 47. AHRQ Publication No. 02-E016 (72). 
cal medial branch nerve blocks, with or without steroids, may provide an effective management strategy for chronic neck pain of facet joint origin. While limitations of this study include a lack of placebo control, the study included an active control in a randomized equivalence or non-inferiority controlled trial, and the study met all the criteria with 60 patients in each group with appropriate outcome measurements.

Manchikanti et al (59) studied the effectiveness of cervical medial branch blocks in chronic neck pain in an observational study. They studied 100 consecutive patients meeting the diagnostic criteria of facet joint pain by means of comparative, controlled diagnostic blocks with $80 \%$ pain relief. They utilized multiple outcome measures including pain relief, psychological status, work status, and functional status. The results showed significant differences in numeric pain scores and significant pain relief ( $\geq 50 \%$ ) at 3 months, 6 months, and 12 months compared to baseline measurements. Improvements were also seen in the functional status, employment status, and psychological functioning. They reported successful outcome in $82 \%$ of the patients at 6 months and $56 \%$ of the patients at 12 months. This is an observational study and it was the first study ever reported on the therapeutic effectiveness of medial branch blocks in the cervical spine. The study included strict inclusion criteria and appropriate outcome measurements.

The therapeutic effectiveness of cervical facet joint medial branch blocks is illustrated in Table 8 for the randomized and observational studies.

\section{Level of Evidence}

The indicated level of evidence is Level II-1 based on the quality of evidence using the USPSTF criteria (80).

\section{Recommendation}

This systemic review found according to Guyatt et al's criteria (104) that the recommendation is strong (1B or 1C) for the use of therapeutic facet joint medial branch blocks to provide both short-term and longterm relief in the treatment of chronic cervical facet joint neck pain.

\section{Radiofrequency Neurotomy}

The literature search revealed 22 studies of radiofrequency neurotomy. Of these, one randomized trial (61) and 4 observational studies $(62,63,110,121)$ met the inclusion criteria for methodologic quality assessment and also for evidence synthesis with methodologic quality scores of $69,87,54,65$, and 50 .

\section{Study Characteristics}

In 1996 Lord et al (61) evaluated the effectiveness of percutaneous radiofrequency neurotomy for chronic cervical zygapophyseal joint pain in 24 patients. This randomized, double blind clinical trial compared percutaneous radiofrequency neurotomy to a sham treatment wherein the procedural technique was the same but radiofrequency was not applied in the control group. Patients with cervical spine pain from automobile accidents were included in the study after comparative diagnostic blocks identified those with cervical facet joint derived neck pain. Subjects then received either the real or sham radiofrequency procedure according to their randomization. Post radiofrequency assessments were performed at 3 to 5 days and at 2 to 3 weeks after the procedure by the same surgeon who was blinded to the treatment groups. At 3 months all patients were formally interviewed by completing the visual-analogue scale and the McGill Pain Questionnaire. Also recorded were the duration

Table 8. Results of published studies of effectiveness of cervical medial branch blocks.

\begin{tabular}{|l|c|c|c|c|c|c|c|c||}
\hline \multicolumn{1}{|c|}{ Study } & $\begin{array}{c}\text { Study } \\
\text { Characteristics }\end{array}$ & $\begin{array}{c}\text { Methodological } \\
\text { Quality Scoring }\end{array}$ & Participants & Pain Relief & \multicolumn{2}{|c|}{ Results } \\
\cline { 5 - 9 } & & 76 & $\begin{array}{c}\text { Group I-no steroid }=60 \\
\text { Group II-steroid }=60\end{array}$ & $\begin{array}{c}83 \% \text { vs } \\
85 \%\end{array}$ & $\begin{array}{c}87 \% \text { vs } \\
95 \%\end{array}$ & $\begin{array}{c}\text { Short- } \\
\text { term } \\
\text { relief } \leq 6 \\
\text { months }\end{array}$ & $\begin{array}{c}\text { Long- } \\
\text { term } \\
\text { relief } \\
\text { months }\end{array}$ \\
\hline $\begin{array}{l}\text { Manchikanti et } \\
\text { al 2008 (60) }\end{array}$ & RA, DB & 12 mos. & P & P \\
\hline $\begin{array}{l}\text { Manchikanti et } \\
\text { al 2004 (59) }\end{array}$ & O & 69 & 100 & $92 \%$ & $82 \%$ & $56 \%$ & $P$ & $P$ \\
\hline
\end{tabular}

$\mathrm{RA}=$ randomized; $\mathrm{DB}=$ double-blind $\mathrm{O}=$ observational; vs = versus; $\mathrm{P}=$ positive 
of their pain, side effects, complications, and any sensation of numbness. At 27 weeks, one patient in the control group and 7 in the active treatment group remained free of pain. The median time for return of pain to at least $50 \%$ of the pre-operative level was 263 days in the active group and 8 days in the placebo group. This study found that radiofrequency neurotomy can provide pain relief for a moderate proportion of patients lasting from months to over a year.

This is a meticulously performed study on a small number of patients; however, the technique is not commonly utilized in the United States. Carragee et al (124) criticized the differences in baseline characteristics of patients among both groups and the nature of the blinding. Carragee et al reported that blinding was in doubt, as $42 \%$ of the active group developed long-term anesthetic or dysesthetic areas of skin and none of the patients in the control group developed changes. They stated that these changes revealed the treatment assigned in nearly half of the active treatment group. With regards to the baseline characteristics the results showed no significant differences based on these differences and also based on litigation. The results showed that $58 \%$ of patients in the control group and $25 \%$ in the active-treatment group had a return of their accustomed pain in the period immediately after the radiofrequency procedure at the 3-month follow-up. Lord et al (61) were unable to avoid such an issue and in fact, this is a problem with any of the sham procedures in interventional pain management. In fact, Dreyfuss and Baker (125) supported Lord et al (61) for maintaining blinding of subjects admirably well and the evidence of difficulty of performing such a study is demonstrated by an extremely limited number of published sham studies involving an invasive treatment. However, Carragee et al (126) maintained their criticism. The small number of patients included in this study also has been an issue, however the study met inclusion criteria.

A study was conducted in 1999 by McDonald et al (63) to determine the long-term efficacy of percutaneous radiofrequency medial branch neurotomy in the treatment of chronic neck pain. This study was created in response to the report by The Quebec Task Force on Whiplash-Associated Disorders (127) that reported there are no valid diagnostic techniques for chronic neck pain and no proven therapy. McDonald et al (63) stated that the report was based on literature that terminated in 1993 and therefore missed the research published since 1993 demonstrating a diagnostic cause and treatment for neck pain following whiplash. Radiofrequency neurotomy was performed between 1991 and 1996 in 28 patients diagnosed with cervical facet joint neck pain by controlled diagnostic blocks. The patients' pain was recorded using a visual analog scale and the McGill Pain Questionnaire (MPQ) prior to radiofrequency neurotomy. Subjects also described 4 activities of daily living that were eliminated or impeded by their pain and that they would want restored if they could be relieved of their pain. One operator performed 30 procedures and another performed 16 procedures during the study. Two other operators performed 3 to 5 procedures for training purposes. Results were tabulated according to operator and the duration of relief obtained to determine whether the outcome was operator dependent. A successful result was defined as complete pain relief for a minimum of 90 days. Twenty-eight patients underwent cervical medial branch neurotomy between March 1991 and October 1996. Initially, 18 of the 28 patients had greater than 3 months of complete pain relief with 421.5 days of median pain relief. The median duration of pain relief for all 28 patients was 218.5 days. Four of the 10 patients who failed to obtain pain relief from the neurotomy did so because of failed radiofrequency equipment, osteophytes preventing correct probe placement, a second pain generator, and a patient who was diagnosed based on comparative diagnostic blocks who later responded to a placebo injection. Repeat radiofrequency neurotomy was performed in 6 of the 10 patients who obtained no relief from the initial treatment and 2 of the patients had greater than 3 months of complete pain relief. Therefore, 20 of the 28 patients $(71 \%)$ obtained complete relief after one or more attempts from radiofrequency neurotomy. Eleven of the 20 subjects underwent repeat neurotomy after pain reoccurrence. This study found that patients can expect between 223 and 730 days of complete relief after an initial procedure and between 144 and 478 days of relief after repeat procedures. This study confirmed again that the relief obtained from radiofrequency medial branch neurotomy should not be expected to be permanent. Repeat radiofrequency neurotomy procedures have been shown to be successful but it is still unknown how many times the operation can be repeated and whether the duration of relief will change. The limitations of this study include inclusion of patients from previous studies and even then a small number of patients with a technique described by Lord et al (61) which is not universally applied.

Sapir and Gorup (62) in 2001 examined the efficacy of radiofrequency medial branch neurotomy to treat 
cervical zygapophysial joint pain from whiplash in an observational study comparing the results of litigants and non-litigants. All patients were involved in an automobile accident at least 20 weeks prior to inclusion in the study and had failed conservative treatment. Those subjects with a positive response to confirmatory diagnostic blocks were enrolled into the study and divided into groups of litigants and non-litigants. Pain was evaluated prior to treatment based on the visual analogue scale (VAS) as well as other outcome measures such as self-report of improvement and change in medication usage. The administration of all questionnaires to the subjects was blind to their legal status, but the treatment operator was not blind to the legal status of the patient. Fifty patients were included in the study meeting the criterion of at least $80 \%$ pain relief from comparative diagnostic blocks and underwent radiofrequency neurotomy. Forty-six patients completed the study consisting of $29(63 \%)$ litigants and $17(37 \%)$ non-litigants. Twenty-one patients (14 litigants and 7 non-litigants) reported a recurrence of pain within one year and 25 patients (15 litigants and 10 non-litigants) remained asymptomatic at one year. Time to pain recurrence defined as $50 \%$ return of pain was approximately $8.3 \pm 2.3$ months in the 21 patients whose pain returned within one year. There was an overall VAS pain reduction of $4.6 \pm 1.8$ from radiofrequency neurotomy at one year with a small but statistically significant difference with litigants having a slightly greater reduction in pain. There were no clinically discernible treatment outcome differences between the litigant and non-litigant groups. In this study radiofrequency neurotomy of cervical facet joint neck pain was found to be an effective treatment for chronic cervical whiplash independent of litigation.

Barnsley (110) assessed outcomes in a series of consecutive patients with percutaneous radiofrequency neurotomy for chronic neck pain. All patients undergoing radiofrequency neurotomy had completed a diagnostic work-up using multiple cervical medial branch blocks, including placebo injections for levels below C2/3. Eligibility criteria included definite or complete relief of pain with both anesthetic agents and no response to placebo under double blind conditions. Electrode positioning was performed in accordance with the protocol of Lord et al (61). The objective of the treatment was to provide complete relief of pain and the primary outcome was the duration of pain relief. The endpoint adapted was the return of any patients usual neck pain, secondary outcomes were the duration of any postoperative pain and any other adverse effects. Outcomes were determined by an independent assessor who had no prior knowledge of the patient and no involvement in the treatment or routine follow-up of patients. Forty-seven procedures were performed on 35 patients, 2 patients were lost to follow-up, 12 patients had 2 procedures, 36 of 45 assessable procedures $(80 \%)$ achieved significant pain relief. These 36 procedures achieved a mean duration of pain relief of 35 weeks, with a median of 35 weeks. Repeat procedures usually achieved reproducible pain relief. Most patients had significant post-procedure pain for about one week. They concluded that radiofrequency neurotomy is an effective palliative treatment for chronic cervical zygapophysial joint pain when performed in routine clinical practice utilizing the technique described by Lord et al (61). Limitations of this study include the lack of generalizability due to utilization of placebo-controlled treatments and the radiofrequency neurotomy technique described by Lord et al (61) which is not universal practice, specifically in the United States, and the small number of patients.

Govind et al (121) evaluated radiofrequency neurotomy for the treatment of third occipital headache with a revised technique using a large gauge electrode ensuring minimum separation between the 3 electrode placements, and holding the electrode in place by hand. The revised technique was used to treat 51 nerves in 49 patients diagnosed as suffering from third occipital headache on the basis of controlled diagnostic blocks of the third occipital nerve. The criteria for successful outcome was complete relief of pain for at least 90 days associated with restoration of normal activities of daily living, and no use of drug treatment for headache. Of the 49 patients, $43(88 \%)$ achieved a successful outcome. The median duration of relief in these patients was 297 days, with 8 patients continuing to have ongoing relief. Fourteen patients underwent a repeat neurotomy to reinstate relief with 12 $(86 \%)$ achieving a successful outcome with a median duration of relief in these patients of 217 days, with 6 patients having ongoing relief. This revised technique apparently improved the success rate greatly compared to the previous technique by Lord et al (119).

Results of medial branch neurotomy in the cervical spine are illustrated in Table 9. All studies had a methodological quality of $\geq 50$ of 100 points. The included studies showed positive short-term and longterm results. 
Table 9. Published results of studies of cervical medial branch neurotomy.

\begin{tabular}{|c|c|c|c|c|c|c|c|}
\hline \multirow{2}{*}{ Study } & \multirow{2}{*}{$\begin{array}{l}\text { Study } \\
\text { Characteristics }\end{array}$} & \multirow{2}{*}{$\begin{array}{c}\text { Methodological } \\
\text { Quality } \\
\text { Score(s) }\end{array}$} & \multirow{2}{*}{$\begin{array}{l}\text { Number of } \\
\text { Patients }\end{array}$} & \multicolumn{2}{|r|}{$\begin{array}{c}\text { Pain Relief } \\
\text { (months) }\end{array}$} & \multicolumn{2}{|c|}{ Results } \\
\hline & & & & 6 mos. & 12 mos. & $\begin{array}{c}\text { Short term } \\
\text { relief } \\
\leq 6 \mathrm{mos} \\
\end{array}$ & $\begin{array}{c}\text { Long term } \\
\text { relief } \\
>6 \mathrm{mos}\end{array}$ \\
\hline Lord et al (61) & $\mathrm{RA}, \mathrm{DB}$ & 67 & 24 & $\begin{array}{l}1 \text { of sham } \\
7 \text { of active }\end{array}$ & $\begin{array}{c}58 \% \\
\text { in active treatment group }\end{array}$ & $\mathrm{P}$ & $\mathrm{P}$ \\
\hline $\begin{array}{l}\text { Sapir and } \\
\text { Gorup (62) }\end{array}$ & $\mathrm{O}$ & 87 & 46 & NA & $\begin{array}{c}\text { Mean VAS change } \\
4.6 \pm 1.8\end{array}$ & $\mathrm{P}$ & $\mathrm{P}$ \\
\hline $\begin{array}{l}\text { McDonald et } \\
\text { al (63) }\end{array}$ & $\mathrm{O}$ & 65 & 28 & NA & $71 \%$ & $\mathrm{P}$ & $\mathrm{P}$ \\
\hline Barnsley (110) & $\mathrm{O}$ & 54 & 35 & NA & $74 \%$ & $\mathrm{P}$ & $\mathrm{P}$ \\
\hline
\end{tabular}

$\mathrm{RA}=$ randomized $; \mathrm{DB}=$ double blind $\mathrm{O}=$ Observational; $\mathrm{NA}=$ not available; $\mathrm{VAS}=$ visual analog scale; $\mathrm{P}=$ positive

Govind et al's study (121) was not included in Table 9 as this was specific for third occipital nerve neurotomy with a specialized technique not applicable to the general population in the United States.

\section{Level of Evidence}

The indicated level of evidence for radiofrequency neurotomy is Level II-1 to II-2 based on one randomized trial $(61)$, and $3(62,63,105)$ observational studies. However, the evidence is based on arriving at the diagnosis with at least $80 \%$ pain relief with controlled diagnostic blocks of either placebo or comparative local anesthetic and utilizing at least 2 lesions at each level based on the descriptions of Lord et al (61), Barnsley et al (110), Sapir and Gorup (62), and McDonald et al (63).

\section{Recommendation}

The systemic review found that according to Guyatt et al's criteria (104), the recommendation is $1 \mathrm{~B}$ or C/strong for radiofrequency neurotomy.

\section{Discussion}

This systematic review provides current evidence for the effectiveness of cervical facet or zygapophysial joint interventions in managing chronic pain of facet joint origin. Based on the results of this evaluation, the evidence for diagnostic facet joint blocks utilizing $80 \%$ pain relief with controlled diagnostic blocks as the criterion standard is Level I or II-1 based on USPSTF criteria. Utilizing 9 studies which met the inclusion criteria, the prevalence of chronic cervical facet joint pain related to neck pain is very common ranging from $36 \%$ to $67 \%$. However, this systematic review based on multiple studies has shown that a single uncontrolled injection is found to be unreliable with a false-positive rate ranging from $27 \%$ to $63 \%$. The prevalence and false-positive rate with a single block was studied in 9 controlled diagnostic evaluations meeting the inclusion criteria with methodologic quality assessment scores $\geq 50$. They showed $\mathrm{Cl}$ ranging from $27 \%$ to $75 \%$, for the prevalence, and $15 \%$ to $78 \%$ for false-positive rate with a single block. One large study (20) showed prevalence of $39 \%(95 \% \mathrm{Cl}$, $32 \%, 45 \%)$ with a false-positive rate of $45 \%(95 \% \mathrm{Cl}$ $37 \%, 52 \%$ ) with a single block.

This systematic review found variable evidence for therapeutic facet joint interventions. There was no evidence available for therapeutic intraarticular cervical facet joint injections. Further, the only study evaluating short-term relief provided negative evidence. Thus, the evidence is strong not to use intraarticular injections for the treatment of chronic facet joint pain in the cervical spine, specifically related to motor vehicle injuries.

In contrast, the evidence is reasonably strong for therapeutic medial branch blocks and radiofrequency neurotomy.

Based on the results of one randomized trial (60) and one observational study (59), the indicated evidence for medial branch blocks has been shown to be Level II-1 with 1B/1C strong recommendation for both short-term and long-term improvement of chronic neck pain. Similarly, based on the radiofrequency neurotomy technique described by multiple investigators $(61-63,110)$ the indicated evidence is Level II-1 to II-2 based on one randomized trial (61) and 3 observational studies $(62,63,110)$. For both therapeutic modalities the patients were selected based on a positive 
response to controlled diagnostic blocks and $80 \%$ pain relief as the criterion standard.

Assessment and grading quality of evidence and providing recommendations for diagnostic tests and strategies is important in all branches of medicine, but specifically in interventional pain management $(72,79-81,128)$. Clinicians often use diagnostic tests as a package or strategy. Interventional pain physicians use a diagnostic strategy which includes signs and symptoms and imaging to identify physiological derangements, establish prognosis, monitor illness, and diagnose $(128,129)$. Consequently, it has been recommended by Schünemann et al (128) that guideline panels considering a diagnostic test or strategy should begin by identifying the patients, diagnostic intervention (strategy), comparison, and outcomes of interest $(130,131)$. The accuracy of a diagnostic test based on the sensitivity and specificity classifies patients correctly as having or not having a disease. The underlying assumption is, however, that obtaining a better idea of whether a target condition is present or absent will result in an improved outcome. Thus, if a test is already available, a new test presumably with superior accuracy must be tested in a randomized controlled trial in which investigators randomize patients to experimental or control diagnostic approaches and measure pain relief, functional status, quality of life improvement, and morbidity (132). To compare the impact of alternative diagnostic strategies on patient-important outcomes, guideline panels can use the Grading of Recommendations Assessment, Development and Evaluation (GRADE) approach $(133,134)$. Further, when such studies are not available, guideline panels must focus on studies of test accuracy and make inferences about the likely impact on patient-important outcomes (135). Thus far in the diagnosis of cervical facet joint pain only one diagnostic strategy is available - controlled diagnostic blocks. This strategy has been proven to be accurate since conventional clinical and radiological techniques, pain patterns, and physical examination findings have been shown to be less than reliable in the diagnosis of facet joint pain (136-140). Even then, controlled comparative local anesthetic blocks have faced significant criticism often based on personal philosophy (137). Further, all the diagnostic and therapeutic evidence included in this systematic review is based on $80 \%$ relief with controlled diagnostic blocks. Thus, at present there is no evidence with $50 \%$ pain relief to maintain diagnostic accu- racy or therapeutic effectiveness $(120,141)$. Factors that decrease the quality of evidence for studies of diagnostic accuracy include study design and risk of bias. Other indirect factors include outcomes, patient populations, diagnostic tests, comparison tests and indirect comparisons, important inconsistency in study results, imprecise evidence, and high probability of publication bias (128). We have attempted in our systematic review to consider all these aspects with utilization of appropriate and strict inclusion criteria and methodologic quality assessment. However, the weakness continues to be with the lack of a criterion standard based on the tissue biopsy. The criterion standard utilized here is a controlled diagnostic block with at least $80 \%$ pain relief and the ability to perform painful movements. This has been supported by significant improvement in patients when the diagnosis was made appropriately and treatment with either medial branch blocks or radiofrequency neurotomy was provided (59-63,108-110).

The diagnosis of facet joint pain by controlled local anesthetic blocks is considered as valid. Controlled diagnostic blocks with 2 local anesthetics with placebo control are the only means of confirming the diagnosis of facet joint pain. The face validity of cervical medial branch blocks has been established by injecting small volumes of local anesthetic and contrast material onto the target points. Construct validity of cervical facet joint blocks is important to eliminate placebo effect as a source of confounding results and to secure truepositive results $(17-25,44,55-57,142,143)$. Further, the hypothesis that testing a patient first with lidocaine and subsequently with bupivacaine provides a means of identifying that the placebo responses have been tested and eliminated (142-145).

Controlled comparative local anesthetic blocks are easier to implement in conventional practice and, therefore, are likely to be preferred and used by physicians unable to perform placebo-controlled blocks specifically in the United States. Further, when compared with placebo-controlled blocks, the false-positive rate has been shown to be very low (143). Therefore, a diagnosis based on comparative blocks is unlikely to be wrong. Cohen et al (120), by proposing a single block, only strengthened the value of comparative local anesthetic blocks rather than weakening it (141). Further, the lack of influence of psychological variables (105), age $(22)$, and sedation $(146,147)$ have been published.

Consequently, we believe that the present systematic review provides strong evidence in favor of con- 
trolled diagnostic blocks in diagnosing cervical facet joint pain with a criterion standard of $80 \%$ pain relief and the ability to perform multiple maneuvers which were painful prior to diagnostic blockade.

Therapeutic medial branch blocks demonstrated effective short- and long-term pain relief for chronic cervical facet joint neck pain. The results for cervical facet joint radiofrequency neurotomy were also positive for short- and long-term pain relief for chronic cervical facet joint neck pain.

This systematic review is different from various systematic reviews performed in the past. First, this systematic review evaluated only cervical facet joint interventions. Second, this systematic review not only evaluated therapeutic facet joint interventions, but also evaluated diagnostic interventions. Third, this systematic review provides evidence which can be applicable with utilization of all 3 techniques. Finally, this systematic review provides a correlation between diagnostic strategy and therapeutic application of the procedure. In addition, this systematic review has utilized both randomized and observational studies with strict inclusion criteria with the application of methodologic quality assessment criteria with a weighted scoring system. Clinical relevance was also evaluated for randomized trials. Consequently, the evidence derived from this systematic review applying strict criteria and robust out- comes, will provide appropriate and sound guidance in managing chronic cervical facet joint pain.

\section{Conclusion}

Diagnostic cervical facet joint nerve blocks are safe, valid, and reliable. Based on the review of available studies that met inclusion criteria, the strength of evidence for diagnostic facet joint techniques is Level I or II-1.

Based on the review of the included therapeutic studies described herein, no evidence is available for cervical intraarticular facet joint injections. The indicated evidence for cervical medial branch blocks is Level II-1 with a strong recommendation of 1B or 1C. The indicated evidence for cervical radiofrequency neurotomy is Level II-1 to Level II-2 with a strong recommendation of $1 \mathrm{~B}$ or $1 \mathrm{C}$.

\section{Acknowledgments}

The authors wish to thank the editorial board of Pain Physician, for review and criticism in improving the manuscript; Vidyasagar Pampati, MSc, statistician; Sekar Edem for assistance in search of literature; and Tonie M. Hatton and Diane E. Neihoff, transcriptionists (Pain Management Center of Paducah), for their assistance in the preparation of this manuscript.

\section{References}

1. Boswell MV, Trescot AM, Datta S, Schultz DM, Hansen HC, Abdi S, Sehgal N, Shah RV, Singh V, Benyamin RM, Patel VB, Buenaventura RM, Colson JD, Cordner HJ, Epter RS, Jasper JF, Dunbar EE, Atluri SL, Bowman RC, Deer TR, Swicegood JR, Staats PS, Smith HS, Burton AW, Kloth DS, Giordano J, Manchikanti L. Interventional techniques: Evidence-based practice guidelines in the management of chronic spinal pain. Pain Physician 2007; 10:7-111.

2. Hogg-Johnson S, van der Velde G, Carroll LJ, Holm LW, Cassidy JD, Guzman J, Côté P, Haldeman S, Ammendolia C, Carragee E, Hurwitz E, Nordin M, Peloso P, Bone and Joint Decade 2000-2010 Task Force on Neck Pain and Its Associated Disorders. The burden and determinants of neck pain in the general population: Results of the Bone and Joint Decade 20002010 Task Force on Neck Pain and Its Associated Disorders. Spine 2008; 33:S39S51.
3. Côté P, Cassidy JD, Carroll L. The Saskatchewan Health and Back Pain Survey. The prevalence of neck pain and related disability in Saskatchewan adults. Spine 1998; 23:1689-1698.

4. Peloso PMJ, Gross A, Haines T, Trinh K, Goldsmith $\mathrm{CH}$, Burnie SJ, Cervical Overview Group. Medicinal and injection therapies for mechanical neck disorders. Cochrane Database Syst Rev 2007; 3: CD000319.

5. Linton SJ, Hellsing AL, Hallden K. A population based study of spinal pain among 35-45-year old individuals. Spine 1998; 23:1457-1463.

6. Bot $\mathrm{SD}$, van der Waal JM, Terwee $\mathrm{CB}$, van der Windt DA, Schellevis FG, Bouter LM, Dekker J. Incidence and prevalence of complaints of the neck and upper extremity in general practice. Ann Rheum Dis 2005; 64:118-123.

7. Croft PR, Lewis $M$, Papageorgiou $A C$, Thomas E, Jayson MI, Macfarlane GJ, Silman AJ. Risk factors for neck pain: A lon- gitudinal study in the general population. Pain 2001; 93:317-325.

8. Côté P, Cassidy JD, Carroll LJ, Kristman V. The annual incidence and course of neck pain in the general population: A population-based cohort study. Pain 2004; 112:267-273.

9. Enthoven P, Skargren E, Oberg B. Clinical course in patients seeking primary care for back or neck pain: A prospective 5year follow-up of outcome and health care consumption with subgroup analysis. Spine 2004; 29:2458-2465.

10. Côté $P$, Kristman V, Vidmar M, Van Eerd D, Hogg-Johnson S, Beaton D, Smith PM. The prevalence and incidence of work absenteeism involving neck pain: A cohort of Ontario lost-time claimants. Spine 2008; 33:S192-S198.

11. Côté $P$, van der Velde $G$, Cassidy JD, Carroll LJ, Hogg-Johnson S, Holm LW, Carragee EJ, Haldeman S, Nordin M, Hurwitz EL, Guzman J, Peloso PM, Bone and Joint Decade 2000-2010 Task Force on Neck 
Pain and Its Associated Disorders. The burden and determinants of neck pain in workers. Results of the Bone and Joint Decade 2000-2010 Task Force on Neck Pain and Its Associated Disorders. Spine 2008; 33:S60-S74.

12. Palmer $K T$, Walker-Bone $K$, Griffin $M J$, Syddall H, Pannett B, Coggon D, Cooper C. Prevalence and occupational associations of neck pain in the British population. Scand J Work Environ Health 2001; 27:49-56.

13. Leroux I, Dionne $\mathrm{CE}$, Bourbonnais $\mathrm{R}$ Brisson C. Prevalence of musculoskeletal pain and associated factors in the Quebec working population. Int Arch Occup Environ Health 2005; 78:379386.

14. Saskatchewan Workers' Compensation Board. Statistical Supplement 2005. www.wcbsask.com/WCBPortal/ShowProperty/WCBRepository/formsPublications/publications/annualPubs/ 2005StatisticalSummary//pdfContent. Accessed date: October 15, 2008.

15. Brattberg $G$, Thorslund $M$, Wikman $A$. The prevalence of pain in a general population. The results of a postal survey in a county of Sweden. Pain 1989; 37:215222.

16. Spitzer WO, Leblanc FE, Dupuis M. Scientific approach to the assessment and management of activity related spinal disorders. Spine 1987; 7:S1-59.

17. Yin W, Bogduk N. The nature of neck pain in a private pain clinic in the United States. Pain Medicine 2008; 9:196-203.

18. Barnsley L, Lord SM, Wallis BJ, Bogduk $\mathrm{N}$. The prevalence of chronic cervical zygapophyseal joint pain after whiplash. Spine 1995; 20:20-26.

19. Lord SM, Barnsley L, Wallis BJ, Bogduk N. Chronic cervical zygapophysial joint pain with whiplash: A placebo-controlled prevalence study. Spine 1996; 21:1737-1745.

20. Manchukonda R, Manchikanti KN, Cash KA, Pampati V, Manchikanti L. Facet joint pain in chronic spinal pain: An evaluation of prevalence and false-positive rate of diagnostic blocks. / Spinal Disord Tech 2007; 20:539-545.

21. Manchikanti L, Boswell MV, Singh V, Pampati V, Damron KS, Beyer CD. Prevalence of facet joint pain in chronic spinal pain of cervical, thoracic, and lumbar regions. BMC Musculoskelet Disord 2004; 5:15.

22. Manchikanti L, Manchikanti K, Cash KA, Singh V, Giordano J. Age-related preva- lence of facet joint involvement in chronic neck and low back pain. Pain Physician 2008; 11:67-75.

23. Manchikanti L, Singh V, Pampati V, Damron $\mathrm{KS}$, Beyer $C D$, Barnhill RC. Is there correlation of facet joint pain in lumbar and cervical spine? An evaluation of prevalence in combined chronic low back and neck pain. Pain Physician 2002; 5:365371.

24. Manchikanti L, Manchikanti K, Pampati V, Brandon D, Giordano J. The prevalence of facet joint-related chronic neck pain in postsurgical and non-postsurgical patients: A comparative evaluation. Pain Pract 2008; 8:5-10.

25. Manchikanti L, Singh V, Rivera J, Pampati, V. Prevalence of cervical facet joint pain in chronic neck pain. Pain Physician 2002; 5:243-249.

26. Speldewinde G, Bashford G, Davidson I. Diagnostic cervical zygapophyseal joint blocks for chronic cervical pain. Med J Aust 2001; 174:174-176.

27. Manchikanti L, Cash K, Pampati V, Fellows B. Influence of psychological variables on the diagnosis of facet joint involvement in chronic spinal pain. Pain Physician 2008; 11:145-160.

28. Fukui S, Ohseto K, Shiotani M, Ohno K, Karasawa H, Naganuma Y, Yuda Y. Referred pain distribution of the cervical zygapophyseal joints and cervical dorsal rami. Pain 1996; 68:79-83.

29. Dwyer A, Aprill C, Bogduk N. Cervical zygapophyseal joint pain patterns: $A$ study in normal volunteers. Spine 1990; 15:453-457.

30. Aprill C, Dwyer A, Bogduk N. The prevalence of cervical zygapophyseal joint pain patterns II: A clinical evaluation. Spine 1990; 15:458-461.

31. Pawl RP. Headache, cervical spondylosis, and anterior cervical fusion. Surg Ann 1977; 9:391-498.

32. Windsor RE, Nagula D, Storm S. Electrical stimulation induced cervical medial branch referral patterns. Pain Physician 2003; 6:411-418.

33. Bogduk $N$. The clinical anatomy of the cervical dorsal rami. Spine 1982; 7:319330.

34. Ohtori S, Takahashi K, Chiba T, Yamagata $M$, Sameda H, Moriya H. Sensory innervation of the cervical facet joints in rats. Spine 2001; 26:147-150.

35. Cavanaugh JM, Lu Y, Chen C, Kallakuri S. Pain generation in lumbar and cervical facet joints. J Bone Joint Surg Am 2006;
88:63-67.

36. Barnsley L, Bogduk N. Medial branch blocks are specific for the diagnosis of cervical zygapophyseal joint pain. Reg Anesth 1993; 18:343-350.

37. Zhang J, Tsuzuki N, Hirabayashi S, Saiki $\mathrm{K}$, Fujita K. Surgical anatomy of the nerves and muscles in the posterior cervical spine. Spine 2003; 1379-1384.

38. Chen $C$, Lu Y, Kallakuri $S$, Patwardhan A, Cavanaugh JM. Distribution of A-delta and C-fiber receptors in the cervical facet joint capsule and their response to stretch. J Bone Joint Surg Am 2006; 88:1087-1816.

39. Chen C, Lu Y, Cavanaugh JM, Kallakuri S, Patwardhan A. Recording of neural activity from goat cervical facet joint capsule using custom-designed miniature electrodes. Spine 2006; 30:1367-1672.

40. Lu Y, Chen C, Kallakuri S. Patwardhan A, Cavanaugh JM. Neurophysiological and biomechanical characterization of goat cervical facet joint capsules. J Orthop Res 2005; 30:779-787.

41. Inami $S$, Shiga $T$, Tsujino A, Yabuki $T$, Okado N, Ochiai N. Immunohistochemical demonstration of nerve fibers in the synovial fold of the human cervical facet joint. J Orthop Res 2001; 19:593-596.

42. Kallakuri S, Singh A, Chen C, Cavanaugh $J M$. Demonstration of substance $P$, calcitonin gene-related peptide, and protein gene product 9.5 containing nerve fibers in human cervical facet joint capsules. Spine 2004; 29:1182-1186.

43. McLain RF. Mechanoreceptors ending in human cervical facets joints. Spine 1994; 5:495-501.

44. Barnsley L, Lord S, Wallis B, Bogduk N. False-positive rates of cervical zygapophysial joint blocks. Clin J Pain 1993; 9:124-130.

45. Bogduk N, Lord S. Cervical zygapophysial joint pain. Neurosurgery 1998; 8:107117.

46. Sehgal N, Dunbar E, Shah R, Colson, J. Systematic review of diagnostic utility of facet (zygapophysial) joint injections in chronic spinal pain: An update. Pain Physician 2007; 10:213-228.

47. Bogduk N. International spinal injection society guidelines for the performance of spinal injection procedures. Part 1: Zygapophyseal joint blocks. Clin J Pain 1997; 13:285-302.

48. Manchikanti L, Singh V, Derby R, Schultz D, Benyamin R, Prager J, Hirsch J. Reassessment of evidence synthesis of oc- 
cupational medicine practice guidelines for interventional pain management. Pain Physician 2008; 11:393-482.

49. Rubinstein SM, van Tulder M. A best-evidence review of diagnostic procedures for neck and low-back pain. Best Pract Res Clin Rheumatol 2008; 22:471-482.

50. Boswell M, Colson J, Sehgal N, Dunbar, E Epter R. A systematic review of therapeutic facet joint interventions in chronic spinal pain. Pain Physician 2007; 10:229-253.

51. Geurts JW, van Wijk RM, Stolker RJ, Groen GJ. Efficacy of radiofrequency procedures for the treatment of spinal pain: A systematic review of randomized clinical trials. Reg Anesth Pain Med 2001; 26:394-400.

52. Niemistö L, Kalso E, Malmivaara A, Seitsalo $\mathrm{S}$, Hurri $\mathrm{H}$, Cochrane Collaboration Back Review Group. Radiofrequency denervation for neck and back pain: A systematic review within the framework of the Cochrane collaboration back review group. Spine 2003; 28:1877-1888.

53. Manchikanti L, Singh V, Vilims BD, Hansen HC, Schultz DM, Kloth DS. Medial branch neurotomy in management of chronic spinal pain: Systematic review of the evidence. Pain Physician 2002; 5:405-418.

54. American College of Occupational and Environmental Medicine. Low Back Disorders Chapter. In: Occupational Medicine Practice Guidelines: Evaluation and Management of Common Health Prob lems and Functional Recovery of Workers, Second Edition. American College of Occupational and Environmental Medicine, Elk Grove Village, 2007.

55. American College of Occupational and Environmental Medicine. Chronic Pain Chapter (revised 2008). In: Occupational Medicine Practice Guidelines: Evaluation and Management of Common Health Problems and Functional Recovery of Workers, Second Edition. American College of Occupational and Environmental Medicine, Elk Grove Village, Epublished August 14, 2008.

56. Manchikanti L, Singh V, Derby R, Helm S, Trescot AM, Staats PS, Prager JP, Hirsch JA. Review of occupational medicine practice guidelines for interventional pain management and potential implications. Pain Physician 2008; 11:271289.

57. Manchikanti L, Singh V, Helm S, Trescot AM, Hirsch JA. A critical appraisal of 2007 American College of Occupational and Environmental Medicine (ACO-
EM) practice guidelines for interventional pain management: An independent review utilizing AGREE, AMA, IOM and other criteria. Pain Physician 2008; 11:291-310.

58. Barnsley L, Lord SM, Wallis BJ, Bogduk N. Lack of effect of intra-articular corticosteroids for chronic pain in the cervical zygapophyseal joints. $N$ Engl J Med 1994; 330:1047-1050.

59. Manchikanti L, Manchikanti K, Damron $\mathrm{K}$, Pampati V. Effectiveness of cervical medial branch blocks in chronic neck pain: A prospective outcome study. Pain Physician 2004; 7:195-201.

60. Manchikanti L, Singh V, Falco FJ, Cash KA, Fellows B. Cervical medial branch blocks for chronic cervical facet joint pain: A randomized double-blind, controlled trial with one-year follow-up. Spine 2008; 33:1813-1820.

61. Lord S, Barnsley L, Wallis B, McDonald $G$, Bogduk N. Percutaneous radio-frequency neurotomy for chronic cervical zygapophyseal-joint pain. $N$ Engl J Med 1996; 335:1721-1726.

62. Sapir DA, Gorup JM. Radiofrequency medial branch neurotomy in litigant and non-litigant patients with cervical whiplash. Spine 2001; 26:E268-E273.

63. McDonald G, Lord S, Bogduk N. Longterm follow-up of patients treated with cervical radiofrequency neurotomy for chronic spinal pain. Neurosurgery 1999; 45:61-67.

64. Manchikanti L, Giordano J. Physician payment 2008 for interventionalists: Current state of health care policy. Pain Physician 2007; 10:607-626.

65. Manchikanti L, Hirsch JA. Issues in Health Care: Interventional pain management at the crossroads. Health Policy Update. Pain Physician 2007; 10:261284.

66. Manchikanti L. Health care reform in the United States: Radical surgery needed now more than ever. Pain Physician 2008; 11:13-42.

67. Manchikanti L. Medicare in interventional pain management: A critical analysis. Pain Physician 2006; 9:171-198.

68. Department of Health and Human Services. Office of Inspector General (OIG). Medicare Payments for Facet Joint Injection Services (OEI-05-07-00200). September 2008. www.oig.hhs.gov/oei/reports/oei-05-07-00200.pdf

69. Specialty Utilization data files from CMS: www.cms.hhs.gov/

70. Manchikanti L, Singh V, Pampati V,
Smith HS, Hirsch J. Analysis of growth of interventional techniques in managing chronic pain in Medicare population: A 10-year evaluation from 1997 to 2006. Pain Physician 2009; 12:9-34.

71. Shojania KG, Sampson M, Ansari MT, Ji J, Doucette S, Moher D. How quickly do systematic reviews go out of date? A survival analysis. Ann Intern Med 2007; 147:224-233.

72. West S, King V, Carey TS, Lohr KN, McKoy N, Sutton SF, Lux L. Systems to Rate the Strength of Scientific Evidence, Evidence Report, Technology Assessment No. 47. AHRQ Publication No. 02E016. Rockville, MD: Agency for Healthcare Research and Quality, 2002. www. thecre.com/pdf/ahrq-system-strength. pdf

73. Atluri S, Datta S, Falco FJ, Lee M. Systematic review of diagnostic utility and therapeutic effectiveness of thoracic facet joint interventions. Pain Physician 2008; 11:611-629.

74. Datta S, Lee M, Falco FJE, Bryce DA, Hayek SM. Systematic Assessment of Diagnostic Accuracy and Therapeutic Utility of Lumbar Facet Joint Interventions. Pain Physician 2009; 12:437460.

75. Manchikanti L, Dunbar EE, Wargo BW, Shah RV, Derby R, Cohen SP. Systematic Review of Cervical Discography as a Diagnostic Test for Chronic Spinal Pain. Pain Physician 2009; 12:305-321.

76. Wolfer L, Derby R, Lee JE, Lee SH. Systematic review of lumbar provocation discography in asymptomatic subjects with a meta-analysis of false-positive rates. Pain Physician 2008; 11:513538.

77. Singh V, Manchikanti L, Shah RV, Dunbar EE, Glaser SE. Systematic review of thoracic discography as a diagnostic test for chronic spinal pain. Pain Physician 2008; 11:631-642.

78. Smith HS, Chopra P, Patel VB, Frey ME, Rastogi R. Systematic review on the role of sedation in diagnostic spinal interventional techniques. Pain Physician 2009; 12:195-206.

79. Rupert MP, Lee M, Manchikanti L, Datta S, Cohen SP. Evaluation of Sacroiliac Joint Interventions: A Systematic Appraisal of the Literature. Pain Physician 2009; 12:399-418.

80. Berg AO, Allan JD. Introducing the third U.S. Preventive Services Task Force. Am J Prev Med 2001; 20:S3-S4.

81. Reid MC, Lachs MS, Feinstein AR. Use of 
methodological standards in diagnostic test research. Getting better but still not good. JAMA 1995; 274:645-651.

82. Whiting $P$, Rutjes A, Reitsma J, Bossuyt P, Kleijnen J. The development of QUADAS: A tool for the quality assessment of studies of diagnostic accuracy included in systematic reviews. BMC Med Res Methodol 2003; 3:25.

83. Bossuyt PM, Reitsma JB, Bruns DE, Gatsonis CA, Glasziou PP, Irwig LM, Lijmer JG, Moher D, Rennie D, de Vet HC; Standards for Reporting of Diagnostic Accuracy. Towards complete and accurate reporting of studies of diagnostic accuracy: The STARD initiative. Clin Chem 2003; 49:1-6.

84. Koes BW, Scholten RJ, Mens JMA, Bouter LM. Efficacy of epidural steroid injections for low-back pain and sciatica: A systematic review of randomized clinical trials. Pain 1995; 63:279-288.

85. Nelemans PJ, Debie RA, DeVet HC, Sturmans F. Injection therapy for subacute and chronic benign low back pain. Spine 2001; 26:501-515.

86. Conn A, Buenaventura R, Abdi S, Diwan S. Systematic review of caudal epidural injections in the management of chronic low back pain. Pain Physician 2009; 12:109-135.

87. Parr AT, Diwan S, Abdi S. Lumbar interlaminar epidural injections in managing chronic low back and lower extremity pain: A systematic review. Pain Physician 2009; 12:163-188.

88. Helm S, Hayek S, Benyamin RM, Manchikanti L. Systematic review of the effectiveness of thermal annular procedures in treating discogenic low back pain. Pain Physician 2009; 12:207-232.

89. Patel VB, Manchikanti L, Singh V, Schultz DM, Hayek SM, Smith HS. Systematic Review of Intrathecal Infusion Systems for Long-Term Management of Chronic Non-Cancer Pain. Pain Physician 2009; 12:345-360.

90. Frey ME, Manchikanti L, Benyamin RM, Schultz DM, Smith HS, Cohen SP. Spinal Cord Stimulation for Patients with Failed Back Surgery Syndrome: A Systematic Review. Pain Physician 2009 12:379-397.

91. Benyamin RM, Singh V, Parr AT, Conn A, Diwan S, Abdi S. Systematic review of the effectiveness of cervical epidurals in the management of chronic neck pain. Pain Physician 2009; 12:137-157.

92. Buenaventura RM, Datta $S$, Abdi $S$ Smith HS. Systematic review of thera- peutic lumbar transforaminal epidural steroid injections. Pain Physician 2009; 12:233-251.

93. Epter RS, Helm S, Hayek SM, Benyamin RM, Smith HS, Abdi S. Systematic Review of Percutaneous Adhesiolysis and Management of Chronic Low Back Pain in Post Lumbar Surgery Syndrome. Pain Physician 2009; 12:361-378.

94. Hayek SM, Helm S, Benyamin RM, Singh V, Bryce DA, Smith HS. Effectiveness of Spinal Endoscopic Adhesiolysis in Post Lumbar Surgery Syndrome: A Systematic Review. Pain Physician 2009; 12:419-435.

95. Staal JB, de Bie R, de Vet HC, Hildebrandt J, Nelemans P. Injection therapy for subacute and chronic low-back pain. Cochrane Database Syst Rev 2008; 3: CD001824.

96. van Tulder $M$, Furlan $A$, Bombardier C, Bouter L, Editorial Board of the Cochrane Collaboration Back Review Group. Updated method guidelines for systematic reviews in the Cochrane Collaboration Back Review Group. Spine 2003; 28:1290-1299.

97. Salaffi F, Stancati A, Silvestri CA, Ciapetti A, Grassi W. Minimal clinically important changes in chronic musculoskeletal pain intensity measured on a numerical rating scale. Eur J Pain 2004; 8:283-291.

98. Bombardier C. Outcome assessments in the evaluation of treatment of spinal disorders: Summary and general recommendations. Spine 2000; 25:31003103.

99. Manchikanti L. Evidence-based medicine, systematic reviews, and guidelines in interventional pain management: Part 1: Introduction and general considerations. Pain Physician 2008; 11:161-186.

100. Manchikanti L, Hirsch JA, Smith HS. Evidence-based medicine, systematic reviews, and guidelines in interventional pain management: Part 2: Randomized controlled trials. Pain Physician 2008; 11:717-773.

101. Manchikanti L, Singh V, Smith HS, Hirsch JA. Evidence-based medicine, systematic reviews, and guidelines in interventional pain management: Part 4: Observational studies. Pain Physician 2009; 12:73-108.

102. Manchikanti L, Benyamin RM, Helm S, Hirsch JA. Evidence-based medicine, systematic reviews, and guidelines in interventional pain management: Part 3: Systematic reviews and meta-analy- sis of randomized trials. Pain Physician 2009; 12:35-72.

103. Manchikanti L, Boswell MV, Giordano J. Evidence-based interventional pain management: Principles, problems, potential, and applications. Pain Physician 2007; 10:329-356.

104. Guyatt G, Gutterman D, Baumann MH, Addrizzo-Harris D, Hylek EM, Phillips B, Raskob G, Lewis SZ, Schünemann H. Grading strength of recommendations and quality of evidence in clinical guidelines. Report from an American College of Chest Physicians Task Force. Chest 2006; 129:174-181.

105. Bogduk N, Aprill C. On the nature of neck pain, discography and cervical zygapophysial joint blocks. Pain 1993; 54:213-217.

106. Saal JS. General principles of diagnostic testing as related to painful lumbar spine disorders. Spine 2002; 27:25382545.

107. Merskey H, Bogduk N. Classification of Chronic Pain. Descriptions of Chronic Pain Syndromes and Definition of Pain Terms, 2nd ed. International Association for the Study of Pain. IASP Press, Seattle, 1994.

108. Manchikanti L, Singh V, Pampati S. Are diagnostic lumbar medial branch blocks valid? Results of 2-year followup. Pain Physician 2003; 5:147-153.

109. Manchikanti L, Damron K, Cash K, Manchukonda R, Pampati V. Therapeutic cervical medial branch blocks in managing chronic neck pain: A preliminary report of a randomized, double-blind, controlled trial: Clinical trial NCT 0033272. Pain Physician 2006; 9:333-346.

110. Barnsley L. Percutaneous radiofrequency neurotomy for chronic neck pain: Outcomes in a series of consecutive patients. Pain Med 2005; 6:282-286.

111. Eden J, Wheatley B, McNeil B, Sox $\mathrm{H}$. Knowing What Works in Health Care: $A$ Roadmap for the Nation. National Academies Press, Washington, DC, 2008.

112. Haspeslagh SR, Van Suijlekom HA, Lame IE, Kessels AG, van Kleef M, Weber WE. Randomised controlled trial of cervical radiofrequency lesions as a treatment for cervicogenic headache: ISRCTN07444684. BMC Anesthesiol 2006; 6:1.

113. Wallis B, Lord S, Bogduk N. Resolution of psychological distress of whiplash patients following treatment by radiofrequency neurotomy: A randomized, double-blind, placebo-controlled trial. 
Pain 1997; 73:15-22.

114. Shin W, Kim H, Shin DG, Shin DA. Radiofrequency neurotomy of cervical medial branches for chronic cervicobrachialgia. J Korean Med Sci 2006; 21:119-125.

115. Folman Y, Livshitz A, Shabat S, Gepstein R. Relief of chronic cervical pain after selective blockade of zygapophyseal joint. Harefuah 2004; 143:339-341, 391.

116. Kim KH, Choi SH, Shin SW, Kim CH, Kim $\mathrm{Jl}$. Cervical facet joint injections in the neck and shoulder pain. J Korean Med Sci 2005; 20:659-662.

117. Schaerer JP. Radiofrequency facet rhizotomy in the treatment of chronic neck and low back pain. Int Surg 1978; 63:5359.

118. Tzaan WC, Tasker RR. Percutaneous radiofrequency facet rhizotomy - experience with 118 procedures and reappraisal of its value. Can J Neurol Sci 2000; 27:125-130.

119. Lord SM, Barnsley L, Bogduk N. Percutaneous radiofrequency neurotomy in the treatment of cervical zygapophysial joint pain: A caution. Neurosurgery 1995; 35:732-739.

120. Cohen SP, Bajwa, Kraemer JJ, Dragovich A, Williams KA, Stream J, Sireci A, McKnight G, Hurley RW. Factors predicting success and failure for cervical facet radiofrequency denervation: A multi-center analysis. Reg Anesth Pain Med 2007; 32:495-503.

121. Govind J, King W, Bailey B, Bogduk N. Radiofrequency neurotomy for the treatment of third occipital headache. J Neurol Neurosurg Psychiatry 2003; 74:8893.

122. Altman DG, Schulz KF, Moher D, Egger M, Davidoff F, Elbourne D, Gøtzsche PC, Lang T; CONSORT GROUP (Consolidated Standards of Reporting Trials). The revised CONSORT statement for reporting randomized trials: Explanation and elaboration. Ann Intern Med 2001; 134:663-694.

123. Piaggio G, Elbourne DR, Altman DG, Pocock SJ, Evans SJ; CONSORT Group. Reporting of noninferiority and equivalence randomized trials: An extension of the CONSORT statement. JAMA 2006; 295:1152-1160.

124. Carragee EJ, Hurwitz EL, Cheng I, Carroll LJ, Nordin M, Guzman J, Peloso P, Holm LW, Côté P, Hogg-Johnson S, van der Velde G, Cassidy JD, Haldeman S, Bone and Joint Decade 2000-2010 Task Force on Neck Pain and Its Associated Disorders.
Treatment of neck pain: Injections and surgical interventions: Results of the Bone and Joint Decade 2000-2010 Task Force on Neck Pain and Its Associated Disorders. Spine 2008; 33:S153-S169.

125. Dreyfuss $P, B a k e r ~ R$. In response to treatment of neck pain. Eur Spine J 2008, 17:1270-1272.

126. Carragee EJ, Hurwitz EL, Cheng I, Carroll LJ, Nordin M, Guzman J, Peloso P, Holm LW, Côté P, Hogg-Johnson S, van der Velde G, Cassidy JD, Haldeman S, Secretariat of the Bone and Joint Decade 20002010 Task Force on Neck Pain and Its Associated Disorders. The authors' reply to the letter to the editor by Paul Dreyfuss et al. Eur Spine J 2008; 17:12731275.

127. Spitzer WO, Skovron ML, Salmi LR, Cassidy JD, Duranceau J, Suissa S, Zeiss E. Scientific monograph of the Quebec Task Force on Whiplash-Associated Disorders: Redefining "whiplash" and its management. Spine 1995; 20:1S-73S.

128. Schünemann $H J$, Oxman $A D$, Brozek J, Glasziou P, Jaeschke R, Vist GE, Williams JW Jr, Kunz R, Craig J, Montori VM, Bossuyt P, Guyatt GH, GRADE Working Group. Grading quality of evidence and strength of recommendations for diagnostic tests and strategies. BMJ 2008; 336:1106-1110.

129. Deeks JJ. Systematic reviews in health care: Systematic reviews of evaluations of diagnostic and screening tests. $B M$ J 2001; 323:157-162.

130. Oxman AD, Guyatt $G H$. Guidelines for reading literature reviews. CMAJ 1988; 138:697-703.

131. Mulrow C, Linn WD, Gaul MK, Pugh JA. Assessing quality of a diagnostic test evaluation. J Gen Intern Med 1989; 4:288-295.

132. Bossuyt PM, Lijmer JG, Mol BW. Randomised comparisons of medical tests: Sometimes invalid, not always efficient. Lancet 2000; 356:1844-1847.

133. Guyatt GH, Oxman AD, Kunz R, Falck-Ytter $Y$, Vist GE, Liberati $A$, Schünemann HJ, GRADE Working Group. Going from evidence to recommendations. $B M$ J 2008; 336:1049-1051.

134. Guyatt GH, Oxman AD, Kunz R, Vist GE, Falck-Ytter $Y$, Schünemann HJ, GRADE Working Group. What is "quality of evidence" and why is it important to clinicians? BMJ 2008, 336:995-998.

135. Lord SJ, Irwig L, Simes RJ. When is measuring sensitivity and specificity suffi- cient to evaluate a diagnostic test, and when do we need randomized trials? Ann Intern Med 2006; 144:850-855.

136. King W, Lau P, Lees R, Bogduk N. The validity of manual examination in assessing patients with neck pain. Spine J 2007; 7:22-26.

137. Bogduk N. In defense of King et al: The validity of manual examination in assessing patients with neck pain. Spine / 2007; 7:749-752.

138. Carragee EJ, Haldeman S, Hurwitz E. The pyrite standard. The Midas touch in the diagnosis of axial pain syndromes. Spine J 2007; 7:27-31.

139. Murphy DR. Validity of manual examination in assessing patients with neck pain. Spine J 2007; 7:508.

140. Abbott JH. Validity of manual examination in assessing patients with neck pain. Spine / 2007; 7:384-385.

141. Manchikanti L, Singh V. Are the results of a multicenter analysis of radiofrequency denervation success as a function of single diagnostic block reliable? Spine J 2008; Sep 12 [Epub ahead of print].

142. Barnsley L, Lord S, Bogduk N. Comparative local anesthetic blocks in the diagnosis of cervical zygapophysial joints pain. Pain 1993; 55:99-106.

143. Lord SM, Barnsley L, Bogduk N. The utility of comparative local anesthetic blocks versus placebo-controlled blocks for the diagnosis of cervical zygapophysial joint pain. Clin J Pain 1995; 11:208213.

144. Bonica JJ, Buckley FP. Regional analgesia with local anesthetics. In: Bonica JJ (ed). The Management of Pain. Lea \& Febiger, Philadelphia, 1990, pp 18831966.

145. Boas RA. Nerve blocks in the diagnosis of low back pain. Neurosurg Clin N Am 1991; 2:806-816.

146. Manchikanti L, Pampati V, Damron KS, McManus CD, Jackson SD, Barnhill RC, Martin JC. A randomized, prospective, double-blind, placebo-controlled evaluation of the effect of sedation on diagnostic validity of cervical facet joint pain. Pain Physician 2004; 7:301-309.

147. Manchikanti L, Pampati V, Damron KS, McManus CD, Jackson SD, Barnhill RC, Martin JC. The effect of sedation on diagnostic validity of facet joint nerve blocks: An evaluation to assess similarities in population with involvement in cervical and lumbar regions (ISRCTNo: 76376497). Pain Physician 2006; 9:47- 